Marquette University Law School

Marquette Law Scholarly Commons

Faculty Publications

Faculty Scholarship

$1-1-2005$

\title{
A Public Interest Model for Applying Lost Chance Theory to Probabilistic Injuries in Employment Discrimination Cases
}

Paul M. Secunda

Marquette UniversityLaw School, paul.secunda@marquette.edu

Follow this and additional works at: http://scholarship.law.marquette.edu/facpub

Part of the Law Commons

Publication Information

Paul M. Secunda, A Public Interest Model for Applying Lost Chance Theory to Probabilistic Injuries in Employment Discrimination Cases, 2005 Wis. L. Rev. 747. Copyright by The Board of Regents of the University of Wisconsin System; Reprinted by permission of the Wisconsin Law Review.

\section{Repository Citation}

Secunda, Paul M., "A Public Interest Model for Applying Lost Chance Theory to Probabilistic Injuries in Employment Discrimination Cases" (2005). Faculty Publications. Paper 555.

http://scholarship.law.marquette.edu/facpub/555

This Article is brought to you for free and open access by the Faculty Scholarship at Marquette Law Scholarly Commons. It has been accepted for inclusion in Faculty Publications by an authorized administrator of Marquette Law Scholarly Commons. For more information, please contact megan.obrien@marquette.edu. 


\title{
A PUBLIC INTEREST MODEL FOR APPLYING LOST CHANCE THEORY TO PROBABILISTIC INJURIES IN EMPLOYMENT DISCRIMINATION CASES
}

\author{
PAUL M. SECUNDA*
}

INTRODUCTION

In the last decade, a growing number of federal courts ${ }^{1}$ have begun to utilize the "loss of a chance" remedial approach" to determine the value of probabilistic injuries ${ }^{3}$ in competitive hiring and promotion cases in the employment discrimination context. ${ }^{4}$ Under this approach, courts

* Assistant Professor of Law, University of Mississippi School of Law. I would like to thank Michael D. Green, Mike Zimmer, and Farish Percy for their thoughtful insights and constructive suggestions on earlier drafts of this Article. I would also like to commend the research assistance of Jeff Farrar, Mississippi Law School Class of 2003, and David Splaingard and Robin Samson, both of the University of Mississippi Law School Class of 2005. Finally, I dedicate this piece to my wife, Mindy Young-Secunda, without whom I would accomplish little.

1. See Doll v. Brown, 75 F.3d 1200, 1206 (7th Cir. 1996) ("[The loss of a chance] basis for an award of damages is not accepted in all jurisdictions, but it is gaining ground ...."). The U.S. Court of Appeals for the Seventh Circuit has taken the lead in applying lost chance theory to employment discrimination cases. See, e.g., Biondo v. City of Chicago, 382 F.3d 680, 688 (7th Cir. 2004); Bishop v. Gainer, 272 F.3d 1009, 1015-17 (7th Cir. 2001); Doll, 75 F.3d at 1205-07.

2. The "loss of a chance" remedial approach, or "lost chance theory," is only one type of recognized proportional liability scheme. Michael D. GREeN, THE FUTURE OF PROPORTIONAL LIABILITY 6 n.13 (Wake Forest Univ. Legal Studies, Research Paper No. 04-14, 2004) available at http://ssrn.com/abstract $=610563$ (to be published in EXPLORING TORT LAw (Stuart Madden ed.) (forthcoming Aug. 2005)); Lars Noah, An Inventory of Mathematical Blunders in Applying the Loss-of-a-Chance Doctrine, 24 REv. LITIG. (forthcoming 2005) (manuscript at 2), available at http://ssrn.com/abstract $=646084$ ("'[L]oss of a chance' represents just one facet of broader debates about probabilistic evidence and proportional recovery in tort law."). See generally John Makdisi, Proportional Liability: A Comprehensive Rule to Apportion Tort Damages Based on Probability, 67 N.C. L. REV. 1063 (1989). Although there are other proportionality schemes, such as "market-share" and "increased risk enhancement," see GREEN, supra, at 6, this Article discusses only lost chance theory and its appropriateness in the employment discrimination context.

3. A "probabilistic injury," as used in this Article, refers to an injury that not only cannot be established with absolute certainty (like most injuries), but also is one for which statistical evidence permits an enhanced evaluation of the relevant probabilities. See GreEn, supra note 2, at 5, 7, 64. Probabilistic injuries in the employment discrimination context generally oecur in the competitive hiring or promotion settings. See Doll, 75 F.3d at 1206 . In these types of cases, it is possible to marshal statistical likelihoods to determine the probabilities of a plaintiff having received the competitive position in the first instance. See infra Part IV.B.2.

4. Because of the uncertainties assoeiated with competitive hiring and promotion cases, lost chance theory has been considered particularly apt in this context. 
discount the value of a job by the probability that the discriminatedagainst plaintiff would have received a competitive position in the absence of discrimination. ${ }^{5}$ For example, if a court finds that a plaintiff had only a $25 \%$ chance of receiving a promotion in the absence of discrimination, the plaintiff is awarded $25 \%$ of the value of that job. ${ }^{6}$ Chief Judge Richard Posner of the U.S. Court of Appeals for the Seventh Circuit, a chief proponent of implementing the lost chance theory in this employment discrimination context, has argued persuasively that such a remedial scheme leads to "more just and equitable results"7 than solely relying upon a "causation inquiry [which] has traditionally had an all-or-nothing effect on the outcome of a tort claim."8

Nevertheless, the application of lost chance theory to these types of employment discrimination cases is not free from controversy. ${ }^{9}$ Critics

Doll, 75 F.3d at 1206. As the Seventh Circuit wrote in Doll: "It strikes us as peculiarly appropriate in employment cases involving competitive promotion [to apply the lost chance theory]. In such a case the plaintiff's chances are inherently uncertain because of the competitive setting." Id. Whether lost chance theory may apply outside of this subset of employment discrimination cases is beyond the scope of this Article.

5. See id.; Joseph H. King, Jr., Causation, Valuation, and Chance in Personal Injury Torts Involving Preexisting Conditions and Future Consequences, 90 YALE L.J. 1353, 1354, 1356 (1980); see also Amy L. Wax, Discrimination as Accident, 74 IND. L.J. 1129, 1220 (1999).

Under a probabilistic scheme, each plaintiff is awarded an amount proportional to the calculated expected contribution of the actionable cause ... to the decision in his case. "The proportionality rule discounts recovery by the probability that the plaintiff's loss was caused by some other wrongdoer, by a nonculpable source, or by the plaintiff."

Wax, supra, at 1220 (quoting David Rosenberg, The Causal Connection in Mass Exposure Cases: A "Public Law" Vision of the Tort System, 97 HaRv. L. Rev. 849, 881 (1984)).

6. See Doll, 75 F.3d at 1206 (setting forth a hypothetical example of how lost chance theory applies in the employment discrimination context). As will be discussed in greater detail below, the $25 \%$ loss of chance derives from the fact that the individual had a $25 \%$ chance of obtaining the position prior to the discrimination and a $0 \%$ chance once discriminatorily denied. See infra Part IV.B.2.

7. See Doll, 75 F.3d at 1207.

8. King, supra note 5, at 1356.

9. See Wax, supra note 5, at 1224-25 (presenting a critique of probabilistic recoveries in employment discrimination cases). Indeed, application of lost chance theory beyond the medical malpractice context continues to be somewhat unsettled. See Restatement (Third) of Torts: Liability For Physical Harm (Basic Principles) § $26 \mathrm{cmt}$. n (Tentative Draft No. 2, 2002); see also David A. Fischer, Tort Recovery for Loss of a Chance, 36 WAKE FOREST L. REV. 605, 610 (2001) (observing that use of loss of a chance is controversial in tort law generally because it is seen as undermining the traditional requirement that damages be proven by a preponderance of the evidence); Jonathan P. Kieffer, The Case for Across-the-Board Application of the Loss-of-Chance Doctrine, 64 DEF. COUNS. J. 568, 568 (1997) ("[T] he loss-of-chance doctrine results in significant inequities for defendants."); Tory A. Weigand, Loss of Chance in Medical Malpractice: A Look at Recent Developments, 70 DEF. Couns. J. 301, 3I1 (2003) 
claim that it is sheer speculation to quantify the probability of a given individual receiving a competitive position in the absence of discrimination. ${ }^{10}$ Unlike the medical malpractice context in which lost chance theory is more commonly utilized, ${ }^{11}$ and where estimations concerning the chance of surviving a deadly disease are based upon past medical experiences of doctors treating patients with similar conditions,${ }^{12}$ the employment context provides no such convenient data to consult. ${ }^{13}$

Even so, the absence of convenient evidence should not diminish the basic soundness of the lost chance approach to probabilistic injuries in competitive hiring and promotion cases. ${ }^{14}$ Echoing Judge Posner to a substantial degree, this Article contends that, although uncertainty will inevitably challenge fact finders to fix percentages for these employment discrimination plaintiffs, ${ }^{15}$ such uncertainty is not insuperable, and is, in

(maintaining that the loss of chance doctrine fundamentally alters causation and lowers the burden of proof in medical malpractice cases). Even so, lost chance theory has made significant inroads in the medical malpractice context in the last twenty-five years or so. See GREEN, supra note 2, at 3-4 ("For the most part, courts have followed Professor King's suggestion that the harm be reconceptualized as a lost opportunity for cure rather than by adopting proportional liability for the adverse outcome.").

10. See Wax, supra note 5, at 1134 (arguing that in the unconscious bias context, "[a] probabilistic system will justify itself neither in producing well-calibrated risk reduction nor in directing compensation to the right persons").

11. Fischer, supra note 9, at 605 ("Tort lawyers in the United States often think of 'loss of a chance' as a theory of 'probabilistic causation' that only applies to medical malpractice misdiagnosis cases.").

12. See id. at 649 (arguing that chance calculations can be based on scientific studies that depend on the etiology of a disease or the characteristics of an injury); King, supra note 5, at 1386 ("One may deduce the probability figure [in medical malpractice cases] from so-called 'relative frequency' by looking at the way in which the same or similar forces operated in the past."). But see GREEN, supra note 2, at 66 ("I wonder about the quality of evidence employed even in medical malpractice lost opportunity cases.").

13. See Doll, 75 F.3d at 1206 ("The difference between employment discrimination and medical and other forms of personal-injury tort is that the relevant probabilities may be more difficult to compute in the employment setting."). The bewildering array of permutations in calculating the probability of an applicant or employee receiving a job exists as a result of competing candidates' overlapping skill sets, numerous personality types (among both candidates and those who hire them), as well as other subjective intangibles, which play differing roles in deciding whether an individual will receive a job or promotion in a competitive circumstance. See Griffin v. Mich. Dep't of Corr., 5 F.3d 186, 189 (6th Cir. 1993); Bryson B. Moore, South Carolina Rejects the Lost Chance Doctrine, 48 S.C. L. REv. 201, 214 (1996) ("A major problem with extending the doctrine to other fields is the greater difficulty in ascertaining the percentage chance lost.").

14. For a discussion on how probabilities can nevertheless still be determined in employment discrimination cases, see infra notes 229-38 and accompanying text.

15. Indeed, all cases involve some degree of uncertainty. GREEN, supra note 2 , at 5 ("Evidence is never perfect; uncertainty always exists."). 
fact, a traditional feature of employment discrimination remedies. ${ }^{16}$ That being said, this Article does part company with Judge Posner over whether a "pure" or "symmetrical" version of lost chance theory" should be applied to so-called "better-than-even" chance cases. ${ }^{18}$

In its place, this Article advocates for, based upon statutory ${ }^{19}$ and prudential $^{20}$ reasons, a public interest model for applying lost chance theory in the employment discrimination context. ${ }^{21}$ Under this hybrid

16. See Int'l Bhd. of Teamsters v. United States, 431 U.S. 324, 372 (1977). "After the victims [of discrimination] have been identified, the court must, as nearly as possible, 'recreate the conditions and relationships that would have been had there been no' unlawful discrimination." Id. (quoting Franks v. Bowman Transp. Co., 424 U.S. 747,769 (1976)). This process of recreating the past will necessarily involve a degree of approximation and imprecision. See Doll, 75 F.3d at 1207 ("Yet no less uncertainty attends the efforts of triers of fact to fix the percentage of a plaintiff's negligence in a tort case governed, as most tort cases are today, by the rule of comparative negligence.") (citations omitted). For a discussion on whether an appropriate analogy exists between comparative negligence and lost chance theory, see infra note 77.

17. By "pure" or "symmetrical," this Article means a version of lost chance theory that advances an across-the-board application of lost chance theory in both highprobability and low-probability employment discrimination cases. Doll, 75 F.3d at 1205-06. But see Michelle L. Truckor, Comment, The Loss of Chance Doctrine: Legal Recovery for Patients on the Edge of Survival, 24 U. DAYTON L. REV. 349, 351 (1999) (arguing for an asymmetrical pure lost chance theory in the tort context). Thus, an applicant with a $75 \%$ chance of being hired would receive $75 \%$ of the value of the job if successful in making out a claim of employment discrimination, not the entire amount as under the traditional all-or-nothing approach. See Doll, 75 F.3d at 1206; see also infra note 22 .

18. In "better-than-even" chance cases, a term coined by Professor Joseph King, a plaintiff has shown that she had a better-than-even chance of securing a favorable result in the absence of the defendant's wrongdoing. King, supra note 5, at 1387. Traditionally, most courts in better-than-even chance cases value the better-thaneven chance as though it had materialized or was certain to do so and award the full value of the job. See id. In contrast, both King and Chief Judge Richard Posner of the U.S. Court of Appeals for the Seventh Circuit advocate pure lost chance theory under which damages are discounted in all cases in order to promote a more accurate loss allocation. See Doll, 75 F.3d at 1206; King, supra note 5, at 1387; see also Truckor, supra note 17 , at 359 .

19. See infra Part III.A.

20. See infra Part III.B.

21. Indeed, the impetus behind this public interest approach derives in part from a recent empirical observation made by Professor Michael Selmi. Michael Selmi, The Price of Discrimination: The Nature of Class Action Employment Discrimination Litigation and Its Effects, 81 TEX. L. REV. 1249, 1252 (2003). In analyzing employment discrimination class action lawsuits, Sclmi found that "[t]here is no longer any concerted effort to eliminate discrimination; instead, efforts are directed at providing monetary compensation for past discrimination without particular concern for preventing future discrimination, or even remedying past discrimination, through injunctive relief." Id. The public interest model to lost chance theory in employment discrimination described in this Article is one attempt to revitalize the important public-regarding aspects of employment discrimination law; albeit through the use of a type of equitable monetary relief rather than through injunctive structural change as Selmi advocates. See 
approach, lost chance theory will be applied in low probability cases where the plaintiff cannot prove a better-than-even chance of having received the position in the absence of discrimination, whereas the traditional "all-or-nothing approach" 22 will apply in high probability, better-than-even chance cases. ${ }^{23}$ This approach is based on the explicit recognition that employment discrimination law, unlike traditional tort law, seeks not only to make victims of discrimination whole, ${ }^{24}$ but also to vindicate the statutory mandate of eradicating all unlawful discrimination from the economy. ${ }^{25}$ As a consequence, the public

\section{id. at 1300; see also infra Part III.A.}

22. As used throughout this Article, the traditional "all-or-nothing approach" refers to a system in which "[c]ompensation is awarded if the plaintiff proves causation and other elements of liability by a designated standard of proof, which in civil actions is a preponderance of the evidence." Wax, supra note 5, at 1212; see also Truckor, supra note 17 , at 354 .

23. See Lori R. Ellis, Note, Loss of Chance as Technique: Toeing the Line at Fifty Percent, 72 Tex. L. REv. 369, 372 (1993) (advocating a similar hybrid approach to lost chance theory in the medical malpractice context).

24. See Zaven T. Saroyan, The Current Injustice of the Loss of Chance Doctrine: An Argument for a New Approach to Damages, 33 CUMB. L. REV. 15, 15 (2002) ("Though the law of torts has many goals, its primary function is to determine when compensation for a harm caused should be required.").

25. Although one of the primary purposes of tort law is also deterrence, see Wax, supra note 5, at 1132-33, tort law seeks to find the appropriate balance of activity and risk. See GREEN, supra note 2, at 62 (describing the law and economics literature in tort law based on the idea "that if actors bear just the right amount of liability for the harm they cause, we will reach an optimal balance between accident costs and prevention costs"). Judge Learned Hand's famous formula of $B<P L$ for determining whether to engage in risky behavior is based on this balance. See United States v. Carroll Towing Co., 159 F.2d 169, 173 (2d Cir. 1947) (stating that an actor's duty "to provide against resulting injuries is a function of three variables . . . if the probability be called P; the injury, L; and the burden, B; liability depends upon whether B is less than L multiplied by P: i.e., whether B < PL"). Id. Title VII of the Civil Rights Act of 1964 ("Title VII"), on the other hand, engages in no such balance, and bans outright all unlawful forms of employment discrimination based on a legislative determination that there is no social value to any of the proscribed forms of employment discrimination. See 42 U.S.C. $\$ 2000 \mathrm{e}-2$ (a)(I) (2000) ("It shall be an unlawful employment practice for an employer-(1) to fail or refuse to hire... any individual, or otherwise to discriminate against any individual with respect to his compensation, terms, conditions, or privileges of employment, because of such individual's race, color, religion, sex, or national origin...."). Not just deterrence, but eradication of unlawful employment discrimination from the workplace is the ultimate goal of laws like Title VII. See Franks v. Bowman Transp. Co., 424 U.S. 747, 771 (1976) ("[T]he denial of seniority relief to victims of illegal racial discrimination in hiring is permissible "only for reasons which, if applied generally, would not frustrate the central statutory purposes of eradicating discrimination throughout the economy and making persons whole for injuries suffered through past discrimination." ") (quoting Albemarle Paper Co. v. Moody, 422 U.S. 405, 421 (1975)) (emphasis added); see also Equal Employment Opportunity Comm'n v. Waffle House, Inc., 534 U.S. 279, 292 (2002) (recognizing that the Equal Employment Opportunity Commission (EEOC) has the statutory authority to vindicate both the private and public interests served by Title VII). 
interest model permits punitive-like equitable relief ${ }^{26}$ against employers as an additional way to effectuate the statutory mandate animating employment discrimination law. ${ }^{27}$

The public interest model will have beneficial effects in at least two important respects. First, it will promote additional deterrence even where the employee is unable to prove a better-than-even chance of receiving a position in the absence of discrimination, thereby eliminating the possibility of a discriminating employer being found completely blameless in circumstances in which unlawful conduct is clearly involved. ${ }^{28}$ Second, and simultaneously, this modified approach will provide additional incentives for employers to take preventive actions to avoid liability, consistent with U.S. Supreme Court precedent in recent employment discrimination cases. ${ }^{29}$

Critics of this model will no doubt argue that this approach is inconsistent with the loss allocation goals of tort law, ${ }^{30}$ and that such an approach will needlessly overcompensate plaintiffs in a punitive manner. ${ }^{31}$ In response, this Article makes a two-prong defense. First, these critics place too much emphasis on the private, "make whole" relief function of employment discrimination law, while paying insufficient heed to plausibly the more important public policy goals of these laws. ${ }^{32}$ Secondly, and connected with the first point, the

26. This Article will contend that "punitive-type" equitable relief is different in kind and nature than traditional punitive damages (which are awarded in employment discrimination law cases under the now familiar Kolstad framework). See infra notes 184-86 and accompanying text.

27. See Waffle House, 534 U.S. at 294-95 ("[W]hile punitive damages benefit the individual employee, they also serve an obvious public function in deterring future violations.") (citing Newport v. Fact Concerts, Inc., 453 U.S. 247, 266-70 (1981)).

28. See Doll, 75 F.3d at 1206 (promoting the lost chance theory in employment discrimination cases as a way to prevent undercompensation and underdeterrence).

29. In both Faragher v. City of Boca Raton, 524 U.S. 775 (1998), and Burlington Industries, Inc. v. Ellerth, 524 U.S. 742 (1998), the U.S. Supreme Court adopted a modified vicarious liability approach in order to give employers incentives to take preventive and corrective actions regarding sexual harassment in the workplace. See Pa. State Police v. Suders, 124 S. Ct. 2342, 2345 (2004) ("[In Faragher and Ellerth,] the Court... recognized that a liability limitation linked to an employer's effort to install effective grievance procedures and an employee's effort to report harassing behavior would advance Title VII's conciliation and deterrence purposes.") (citing Ellerth, 524 U.S. at 764); see also Faragher, 524 U.S. at 807. The proposed remedial approach in this Article satisfies these same prophylactic interests. See infra notes 190-94 and accompanying text.

30. See King, supra note 5, at 1387.

31. See Wax, supra note 5, at 1134 .

32. See Albemarle Paper, 422 U.S. at 418; see also Franks, 424 U.S. at 779 n.40 (1976) ("'[C]laims under Title VII involve the vindication of a major public interest....") (quoting a section-by-section analysis accompanying the EQUAL EMPLOYMENT OPPORTUNITY ACT OF 1972 CONFERENCE REPORT, 118 CONG. REC. 7166, 7168 (1972)) (alteration in original) (emphasis added). 
concededly punitive aspects of overcompensating plaintiffs in betterthan-even chance cases should be embraced, rather than rejected, as being consistent with the broader statutory mandate of these laws: to protect the public from the insidious consequences of discriminatory employer conduct. ${ }^{33}$ In all, the public interest model is most consistent with the "central statutory purposes" 34 served by federal antidiscrimination legislation. ${ }^{35}$

This Article presents the public interest model for applying lost chance theory to probabilistic injuries in employment discrimination cases in four parts. Part I explores the underlying mechanics of pure lost chance theory as developed by Professor Joseph King, as well as its first important practical tort application in the seminal case Herskovits $v$. Group Health Cooperative of Puget Sound. ${ }^{36}$ Part II then evaluates Judge Posner's suggestion that pure lost chance theory should apply to probabilistic injuries in employment discrimination cases, as well as the theory's subsequent adoption by the Seventh Circuit in the employment discrimination cases of Bishop v. Gainer ${ }^{37}$ and Biondo v. City of Chicago. ${ }^{38}$ Part III asserts that pure lost chance theory conflicts with both statutory and prudential concerns underlying federal employment discrimination laws. To remedy these deficiencies, Part IV advances a public interest model for applying lost chance theory to probabilistic injuries in competitive hiring and promotion cases, thus providing a more consistent approach with regard to the public policy underlying the employment discrimination laws.

33. See Waffle House, 534 U.S. at 295. As the U.S. Supreme Court stated in Waffle House:

we are persuaded that, pursuant to Title VII and the [Americans with Disabilities Act of 1990], whenever the EEOC chooses from among the many charges filed each year to bring an enforcement action in a particular case, the agency may be seeking to vindicate a public interest, not simply provide make-whole relief for the employee, even when it pursues entirely victim-specific relief.

Id.

34. See supra note 25.

35. By federal antidiscrimination legislation, this Article has in mind statutes like the Equal Pay Act, 29 U.S.C. \$ 206(d); the Age id. U.S.C. \$ 791; 42 U.S.C. § 1981 ("Section 1981"); Title VII, id. $\$ \$ 2000$ e to 2000e-17; and the Americans with Disabilities Act of 1990 (ADA), id. \$\$ 12101-12117.

36. 664 P.2d 474 (Wash. 1983) (en banc).

37. 272 F.3d 1009 (7th Cir. 2001).

38. 382 F.3d 680 (7th Cir. 2004). 


\section{THE RUDIMENTS OF LOST CHANCE THEORY}

\section{A. The Theoretical Underpinnings: Separating Causation from Valuation}

In his seminal piece on lost chance theory, King complained that courts in tort cases were guilty of applying the concept of causation improperly to matters of valuation. ${ }^{39}$ Whereas causation concerns "the cause and effect relationship that must be established between tortious conduct and a loss before liability for that loss may be imposed,"40 valuation involves "the process of identifying and measuring the loss that was caused by the tortious conduct." 11 Put more succinctly, whereas causation concerns whether a plaintiff should recover for a loss, valuation concerns how much the plaintiff should recover for a loss. ${ }^{42}$

Nevertheless, many courts today still follow an all-or-nothing approach ${ }^{43}$ under which the interest in a favorable outcome is either redressed completely or completely ignored. ${ }^{44}$ In other words, these courts treat "the chance of avoiding a loss as if it were either a certainty or impossibility," and thus, "the plaintiff will recover for a lost opportunity only if it appears more likely than not that but for the tort some definitive adverse result would have been avoided."45 Contrariwise, if the probability of the lost chance does not rise above $50 \%$, the plaintiff cannot meet her burden and recovers nothing under the traditional all-or-nothing rule. ${ }^{46}$ Thus, even if a plaintiff can show definitively that a defendant has engaged in tortious conduct, which has caused a loss of a chance of avoiding harm or of receiving a future benefit, under the all-or-nothing approach the plaintiff recovers no compensation. ${ }^{47}$ To King and other commentators, this outcome appears overly harsh and unnecessary. ${ }^{48}$

39. See King, supra note 5, at 1353 (recognizing a tendency to commingle the concepts of causation and valuation); id. at 1363 ("What caused a loss . . . should be a separate question from what the nature and extent of the loss are.").

40. Id. at 1363. In other words, "[c]ausation questions relate to the fact of a loss or of its source." Id. at 1353-54.

41. Id. at 1354.

42. See id. at 1389.

43. Fisher, supra note 8, at 605-06.

44. See Restatement (THIRD) OF TORTs, supra note $9, \S 26 \mathrm{cmt}$. n (citing DAN B. DOBBS, THE LAW OF TORTS $§ 178$, at $435 \&$ n. $1(2000)$ ).

45. King, supra note 5 , at 1365 .

46. See Fischer, supra note 9 , at 605-06.

47. See King, supra note 5, at 1356 ("Unless a causal connection is established under the applicable standard of proof . . . the plaintiff will receive nothing for the loss in question.").

48. See Herskovits, 664 P.2d at 477 (arguing that the traditional all-or-nothing approach in medical malpractice context results in "a blanket release from liability for 
Seeking to rectify this unsatisfactory legal state of affairs, King advanced the notion that courts should treat the chance at a favorable outcome as a compensable interest in its own right. ${ }^{49}$ Specifically he suggested that, "the loss of a chance of achieving a favorable outcome or of avoiding an adverse consequence should be compensable and should be valued appropriately, rather than treated as an all-or-nothing proposition." 50 Thus, even in cases where the opportunity at a favorable outcome was not better than even, the interest lost thereby should still be appropriately valued. ${ }^{51}$ Furtherinore, he argued for an across-the-board application, referred to herein as "pure loss of chance theory." 52 Under pure loss of chance theory, even in cases where the opportunity at a favorable outcome is better than even, the loss of interest is not treated as a certainty, but valued based on the probability that the plaintiff would have received a benefit or avoided harm. ${ }^{53}$

doctors and hospitals any time there was less than a 50 percent chance of survival, regardless how flagrant the negligence"); King, supra note 5, at 1373. As King wrote: "The plaintiff who is able to demonstrate a probability of $50 \%$ or less that some future loss attributable to the tort will occur will be demied redress for that prospective loss. Yet it is mamifest that the plaintiff's interests have been adversely affected." King, supra note 5, at 1373; see also Fischer, supra note 9, at 618 ("There is no theoretical basis for requiring that defendant completely destroy the chance in order to be subject to liability.").

49. See King, supra note 5, at 1373; see also Todd S. Aagaard, Note, Identifying and Valuing the Injury in Lost Chance Cases, 96 MicH. L. REv. 1335, 133839 (1998) (criticizing courts and commentators for failing to properly identify the precise tort injury in lost chance cases). In this manner, King sought to value the true interest lost when future expectancies were at stake. See King, supra note 5, at 1373; see also Fischer, supra note 9, at 605 ("[1]f a physician negligently fails to diagnose a curable disease, and the patient is harmed by the disease, the physician should be liable for causing the 'loss of a chance' of a cure.").

50. King, supra note 5, at 1354; see also Fischer, supra note 9, at 617 ("A major rationale for loss of a chance where plaintiff cannot prove traditional damage is that the chance of obtaining a benefit or avoiding a harm has value in itself that is entitled to legal protection.").

51. King, supra note 5, at 1354. Identifying the interest harmed as the "loss of a chance" in these cases may lead to another difficult issue: "whether persons deprived of an opportunity of avoiding harm who nevertheless do not suffer the harm may recover for the lost opportunity." RESTATEMENT (THIRD) OF ToRTs, supra note $9, \S 26 \mathrm{cmt}$. n. As discussed below, however, commentators have made a distinction between lost chance theory where the harm has already occurred as opposed to increased risk theory, where the future harm is still speculative. See infra note 92 . In any event, although this distinction is clearly important in the medical malpractice context, it is less likely to be so in the employment discrimination context in which lost chance will apply only if employer liability has been established for engaging in unlawful discrimination in the first instance. See infra Part II. A.

52. See Truckor, supra note 17 , at 358 (defining "pure loss of a chance theory").

53. King, supra note 5, at 1376. According to King: "Loss of a chance should be compensable even if the chance is not better than even, and it should be recognized and valued as such rather than an all-or-nothing proposition. Any other rule fails to 


\section{B. The Cancer Misdiagnosis Hypothetical}

In order to more clearly explain how King's lost chance theory operates in practice, it is helpful to compare the manner in which many jurisdictions to this day still resolve these tort issues under the all-ornothing approach, as compared to how the lost chance theory would apply in similar circumstances. The most common scenario contemplated for these purposes, and in fact derived from a scenario set out by King himself, occurs in the medical malpractice context..$^{54}$

Under this scenario, a patient goes to the doctor on date $X$ and receives a clean bill of health. Three months later on date $Y$, that same patient goes to the same doctor, is diagnosed with cancer, and is told that she has now only a $10 \%$ chance of surviving the cancer. If the patient had been properly diagnosed on date $X$, she would have had a $40 \%$ chance of surviving the cancer. Unfortunately, the patient eventually dies from the cancer and her estate brings an action in state court. ${ }^{55}$

satisfy the goals of tort law." Id. For example, where the plaintiff could prove that, absent discrimination, he would have had a $95 \%$ chance of receiving the position in question, under pure loss of a chance theory he should receive $95 \%$ of the value of the job, not $100 \%$ as would be awarded under the traditional all-or-nothing rule. See Truckor, supra note 17, at 367-68.

54. King, supra note 5, at 1363-64. Although medical malpractice is the context in which most commentators have analyzed lost chance theory, others have recognized that this remedial approach can apply in various areas of tort law, including failures to rescue, to warn, to provide safety devices, and to give informed consent to medical procedures. See Fischer, supra note 9, at 606. But see Noah, supra note 2 (manuscript at 10) ("Those jurisdictions that recognize clainis for the loss of less-thaneven odds generally have not extended the theory beyond the medical malpractice context.").

55. Assuming, as we do in the hypothetical above, that the patient dies as a result of the negligent misdiagnosis, a survivorship action rather than a wrongful death action should be brought under a lost chance theory because in a wrongful death action, beneficiaries sue in their own right, not as a representative of the deceased person's estate. See Truckor, supra note 17, at 372-73. Because the beneficiaries of the deceased have not themselves lost a chance of recovery as a result of the negligence, they would not appear to have a wrongful death action. See id. at 372; see also Edwards v. Family Practice Assoc., 798 A.2d 1059, 1063 (Del. 2002) (finding a survivorship claim to be a nore appropriate cause of action than a wrongful death action in a loss of chance case). On the other hand, a wrongful death action would properly be brought under an all-or-nothing approach under which a plaintiff is seeking recovery for the ultimate harm (that is, the death of the patient). See, e.g., Cooper v. Sisters of Charity of Cincinnati, Inc., 272 N.E.2d 97, 104 (Ohio 1971). 
Table A

Hypothetical Loss of a Chance Medical Malpractice Scenario

\begin{tabular}{|c|c|c|}
\hline Visit to Doctor & Diagnosis & $\begin{array}{c}\text { Chance of } \\
\text { Surviving Cancer }\end{array}$ \\
\hline Date $X$ & Clean Bill of Health & $40 \%$ chance \\
\hline $\begin{array}{c}\text { Date } Y \\
\text { (3 months later) }\end{array}$ & Cancer Diagnosis & $10 \%$ chance \\
\hline
\end{tabular}

Under the traditional all-or-nothing approach, the question posed would be whether the plaintiff could prove by the preponderance of the evidence that the doctor's negligence in misdiagnosing the patient's cancer more likely than not caused the patient's death. ${ }^{56}$ In this analysis, the plaintiff seeks redress for the patient's premature death in terms of the value of that patient's life to others had she lived. ${ }^{57}$ However, because the patient never had more than a $40 \%$ chance of surviving the cancer (even under the best case scenario of being properly diagnosed on date $X$ ), the plaintiff will not be able to meet her evidentiary burden of establishing that the doctor's negligent actions caused the patient's death. ${ }^{58}$ Thus, under the all-or-nothing approach, the plaintiff would receive no recovery, even though the doctor has clearly engaged in some negligence and harmed the patient in some real way by the misdiagnosis. ${ }^{59}$

Under the loss of a chance approach, the critical distinction is how the court identifies the interest that has been destroyed. ${ }^{60}$ Whereas the interest thought to be harmed in the all-or-nothing approach is the life of

56. Put slightly differently, the question would be whether the doctor's negligence was a "but for" cause of the plaintiff's injury. See King, supra note 5, at 1355,1367 ("[T]he all-or-nothing . . . rule denies compensation for the loss of a notbetter-than-even chance of avoiding some adverse result.").

57. See id. "Damages in personal injury tort actions are traditionally awarded in a single lump sum that is intended fully to compensate the plaintiff for all past and future consequences of the tort." Id. at 1370. Consequently, in valuing the life of the deceased patient, a court will have to consider such factors as life expectancy (based on such factors as age and health), loss of future earnings, and injury caused to others by the loss of that person's companionship (that is, consortium). See id. at 1382. Moreover, the prospect of such future losses must be proven with "reasonable certainty." Id. at 1371. "Reasonable certainty," in turn, is defined as lying "somewhere between speculation and actual certainty." Id.

58. To reiterate, this is because preponderance of the evidence (more than $50 \%$ likelihood) is the standard of proof in most civil actions. See Wax, supra note 5, at 1212.

59. See King, supra note 5, at 1373. This characterization assumes, of course, that the patient actually died. For a discussion on the difference between lost chance claims and increased risk claims depending upon whether the patient has died as a result of the negligent misdiagnosis, see infra note 88.

60. See King, supra note 5, at 1370. 
the patient (that is, the ultimate harm), lost chance theory focuses instead on the loss of opportunity of survival by the patient (that is, an intermediate harm) ${ }^{61}$ Under lost chance theory, therefore, the causation inquiry devolves into a more easily satisfied inquiry: whether the plaintiff can establish by the preponderance of the evidence that the doctor's negligent malpractice caused the destruction of a certain degree of chance that the patient had at survival. ${ }^{62}$ In most cases of this type, the answer to this refined causation question will be "yes."

What remains, then, is the valuation inquiry; that is, once one recognizes that the loss of a chance is a cognizable interest for which redress may be sought, one must decide how to go about valuing that interest. $^{63}$ Initially, in valuing the extent of the loss, the preinjury condition or preexisting condition of the victim should be taken into account. ${ }^{64}$ To do this, the court simply takes the difference between the chance of survival prenegligence and the chance of survival postnegligence and then multiplies this figure by the value of the individual's life had she lived. ${ }^{65}$ To be more concrete, if the patient's life was valued at $\$ 100,000$ and the loss of opportunity is quantified as $30 \%$ ( $40 \%$ prenegligence chance minus $10 \%$ postnegligence chance),

61. See id.

62. Id. at 1394 (" $[\mathrm{W}]$ hile the loss of a not-better-than-even chance of avoiding some adverse result should be a compensable loss, it still must be established that the defendant caused the destruction of that chance."). In other words, "the all-or-nothing idea may continue to be applied to causation even if it is abandoned for the purposes of valuation." Id. at 1395; see also Truckor, supra note 17, at 358 . This crucial point appears to be the most difficult distinction to grasp for opponents of the lost chance approach. See, e.g., Weigand, supra note 9, at 301 ("The effect of the [theory of recovery] is that it alters the traditional 'more likely than not' burden of proof."); see also Jones v. Owings, 456 S.E.2d 371, 374 (S.C. 1995) ("We are persuaded that the 'the loss of chance doctrine is fundamentally at odds with the requisite degree of medical certitude necessary to establish a causal link between the injury of a patient and the tortious conduct of a physician.' ") (emphasis added) (quoting Kilpatrick v. Bryant, 868 S.W.2d 594, 602 (Tenn. 1993)).

63. See King, supra note 5, at 1381.

64. Id at 1356,1385 . In this scenario, the preexisting condition could be defined as "a disease, condition, or force that has become sufficiently associated with the victim to be factored into the value of the interest destroyed, and that has become so before the defendant's conduct has reached a similar stage." Id. at 1357 (citing William Prosser, HANDBOOK OF THE LAW OF TORTS § 52, at 321-22 (4th ed. 1971)).

65. This approach is based on the "conjunction principle." See King, supra note 5 , at 1382,1389 ("A better method of valuation would measure a compensable chance as the percentage probability by which the defendant's tortious conduct diminished the likelihood of achieving some more favorable outcome."). The reason why the calculation works in this manner is because "'mathematical probability obeys a multiplicative conjunction principle, whereby the probability that two independent events both occur is equal to the mathematical product of their individual probabilities." Id. at 1388 (quoting L.J. Cohen, The Probable and the Provable 51-52 (1977)); see also id. at 1389 ("The conjunction principle should be an indispensable feature of the valuation process."). 
then the plaintiff should be able to recover $\$ 30,000$ under these circumstances. This number more closely represents the harm caused by the doctor's misdiagnosis. ${ }^{66}$

The advantage of this outcome in not-better-than-even-chance cases is that the plaintiff will not be overcompensated unnecessarily for the value of her remaining life when the cancer in all probability would have killed her anyway. ${ }^{67}$ At the same time, the patient is not undercompensated, although the doctor's actions may not have literally caused her death, because the doctor's action did make the patient's death more likely, and the chance of avoiding that adverse consequence should be quantified in some manner. ${ }^{68}$ Concerns of fairness also counsel for an approach that provides some recovery for the patient's lost chance of survival because it is the doctor's negligence after all that has made it impossible to determine with any certainty what would have

66. Some commentators have described a different type of valuation analysis based on the "increase of relative risk" or "attributable risk" for lost chance cases in the medical malpractice context. See RICHARD A. EPSTEIN, TORTS 253-54 (1999) (describing the increase of the relative risk model); Noah, supra note 2 (manuscript at $28 \mathrm{n.88}$ ) (concluding that the attributable risk calculation provides clarity by converting loss-of-a-chance claims into evaluations of relative risk); see also Aaron D. Twerski \& Neil B. Cohen, The Second Revolution in Informed Consent: Comparing Physicians to Each Other, 94 Nw. U. L. REv. 1, 28 n.68 (1999) (applying the relative risk model to informed consent claims). Under these approaches, the fact finder seeks to determine the likelihood that the doctor's negligence caused the patient's ultimate injury. See Noah, supra note 2 (manuscript at 27) (noting that an attributable risk of 53\% establishes that "the defendant's negligence probably caused the ultimate injury"). But, as the Supreme Court of New Mexico has rightly pointed out:

[U]nder the lost-chance theory, the patient does not allege that the malpractice caused his or her entire injury. Rather, the claim is that the health care provider's negligence reduced the chance of avoiding the injury actually sustained. Thus, it is that chance in and of itself-the lost opportunity of avoiding the presenting problem and achieving a better result-that becomes the item of value for which the patient seeks compensation.

Alberts v. Schultz, 975 P.2d 1279, 1283 (N.M. 1999) (citations omitted). In short, both the relative risk and attributable risk methods focus on the ultimate injury rather than the lost opportunity, and therefore, represent just another method of proving traditional tort causation. See Noah, supra note 2 (manuscript at 32, 36) (recognizing this criticism to his approach, but suggesting that the attributable risk approach will limit the cases in which loss of chance analysis has to be utilized in the first place). In this sense, these types of analyses are not properly categorized as loss of chance approaches to tort recovery.

67. See King, supra note 5, at 1387.

68. See id. at 1377 . As King wrote:

The all-or-nothing approach to loss of a chance . . . subverts the deterrence objectives of tort law by denying recovery for the effects of conduct that causes statistically demonstrable losses. By placing such losses outside tort law, the all-or-nothing approach distorts the loss-assigning role of that law.

Id. 
happened absent the negligence. ${ }^{69}$ All in all, King asserted that his approach of valuing the interest harmed by the defendant's conduct best supported the loss allocation and deterrence goals of tort law. ${ }^{70}$

\section{Criticisms Surrounding the Lost Chance Approach}

Although lost chance theory can claim the advantages discussed in the preceding Section, criticisms of this approach abound and only fourteen states (at the time of the writing of this Article) have clearly adopted a lost chance theory in the medical malpractice context. ${ }^{71}$ The criticisms of the lost chance approach can be categorized into two main groups: (1) the inevitable problems surrounding the valuation of a loss of a chance and subsequent jury confusion on the remedial issues to be decided $;^{72}$ and (2) the lack of a principled basis for limiting application of loss of a chance to a certain range of cases. ${ }^{73}$

First, with regard to the concern that valuing these losses of chance is incredibly complex, it might be true to an extent that to put a value on such opportunities may be little more than an elaborate, arbitrary guessing game. ${ }^{74}$ Moreover, as confusing as civil litigation is today for

69. See id. at 1378 .

70. See id. at 1381 (arguing that the all-or-nothing approach "undermines the loss-assigning function of tort law by improperly externalizing significant costs of various enterprises").

71. These fourteen states are: Arizona (Thompson v. Sun City Cmty. Hosp., Inc., 688 P.2d 605 (Ariz. 1984)); Indiana (Cahoon v. Cummings, 734 N.E.2d 535, 539-41 (Ind. 2000)); Iowa (Wendland v. Sparks, 574 N.W.2d 327, 331-32 (Iowa 1998)); Kansas (Delaney v. Cade, 873 P.2d 175, 184-87 (Kan. 1994)); Louisiana (Gordon v. Willis Knighton Med. Ctr., 661 So. 2d 991, 999-1001 (La. Ct. App. 1995)); Missouri (Wollen v. DePaul Health Ctr., 828 S.W.2d 681, 683-86 (Mo. 1992)); Nevada (Perez v. Las Vegas Med. Ctr., 805 P.2d 589, 591-93 (Nev. 1991)); New Hampshire (Lord v. Lovett, 770 A.2d 1103, 1106 (N.H. 2001)); New Jersey (Scafadi v. Seiler, 574 A.2d 398, 405-06 (N.J. 1990)); New Mexico (Alberts, 975 P.2d at 128283); Ohio (Roberts v. Ohio Permanente Med. Group, Inc., 668 N.E.2d 480, 484-85 (Ohio 1996)); Oklahoma (McKellips v. St. Francis Hosp., Inc., 741 P.2d 467, 474-77 (Okla. 1987)); Washington (Herskovits, 664 P.2d at 477); and Wyoming (McMackin v. Johnson City Healthcare Ctr., 73 P.3d 1094, 1 I00 (Wyo. 2003)). Although Michigan (Falcon v. Mem'l Hosp., 462 N.W.2d 44 (Mich. 1990)), and South Dakota (Jorgensen v. Vener, 616 N.W.2d 366, 370-71 (S.D. 2000)) initially adopted lost chance theory judicially, the theory has now been legislatively abrogated in these states in the medical malpractice context. See Mich. CoMP. LAWS ANN. § 600.2912a(b)(2) (2000); S.D. CODE ANN. § 20-9-1 (Lexis Supp. 2002).

72. See Noah, supra note 2 (manuscript at 3) (suggesting that lost chance theory mathematical calculations may pose too great of a challenge for both litigants and decision-makers).

73. Moore, supra note 13 , at 214.

74. See Fischer, supra note 9, at 621 (maintaining that the application of lost chance theory may lead to "widely speculative damages" as a result of little evidence concerning the magnitude of the loss of chance); Wax, supra note 5, at 1224 (" $\mathrm{A}$ probabilistic rule that requires assigning a precise probability to the elements . . that 
the average juror, the last thing we need, the argument goes, is a further complication of the issues in dispute. ${ }^{75}$ Be that as it may, these types of conjectures also occur both in normal causation analysis ${ }^{76}$ and in the comparative negligence setting, ${ }^{77}$ and yet juries are commonly asked to rely on their innate sense of fairness and common sense. ${ }^{78}$ ln any event, using probability analysis to engage in transparent ${ }^{79}$ loss valuations is still preferable to maintaining the use of the all-or-nothing approach with its harsh, arbitrary, and unfair results. ${ }^{80}$

contribute to any workplace decision would strain the fact-finding capability of a liability system to the breaking point."); $c f$. Laurence Tribe, Trial by Mathematics. Precision and Ritual in the Legal Process, 84 HARV. L. REV. 1329, 1377 (1971) (arguing that "the costs of attempting to integrate mathematics into the factfinding process of a legal trial outweigh the benefits").

75. See Truckor, supra note 17, at 364 (observing that lost chance theory is confusing to juries and statistics can be easily manipulated by experts); see also Fennell v. S. Md. Hosp. Ctr., Inc., 580 A.2d 206, 213-14 (Md. 1990) (refusing to adopt lost chance theory because of concern about misuse of "unreliable, misleading, easily manipulated, and confusing" statistical information). Nevertheless, as discussed below, the difficulty of calculating probabilities may be somewhat assuaged in the employment discrimination eontext where judges will be primarily responsible for calculating lost chance values. See infra note 208 and accompanying text.

76. See Jorgensen, 616 N.W.2d at 371 (maintaining that the fact that lost chance doctrine relies on statistical evidence "in order to assign a value to the lost chance" does not make the theory more speculative because "such use of mathematical calculations is already necessary under traditional standards of causation" to show that the plaintiff once enjoyed a greater than even chance of surviving), abrogated by legislative amendment, S.D. CODIFIED LAWs § 20-9-1.

77. Some may argue that comparing lost chance analysis to comparative negligence analysis is inapt because lost chance deals with probabilities about some occurrence in the real world, while comparative fault involves a normative assessment and, therefore, has no objective measure (the author would like to thank Professor Michael D. Green for sharing his views on this particular topic). Although I agree with Green's view of the two concepts, nevertheless, both analyses are similar in requiring apportionments that would appear to permit a plaintiff to recover without proving that thc defendant's negligence more probably than not caused her injury. See Noah, supra note 2 (manuscript at 25) ("[N]ow that many courts fully apportion damages among litigants according to their share of responsibility for an injury, the loss-of-a-chance theory as an issue of valuation rather than causation no longer looks so terribly radical.").

78. See Truckor, supra note 17 at 366 ("Juries are typically permitted to rely on their own intuition and experience in calculating damages in negligence cases ....").

79. By transparency, I mean the basic proposition that things go better when processes are open. See Lawrence Solum, Legal Theory Lexicon: Transparency, LEGAL THEORY BLOG (Dec. 21, 2003), at http://lsolum.blogspot.com/archives/ 2003_12_01_lsolum_archive.html 107201605073347259.

80. Fischer, supra note 9, at 640 ("It is better that plaintiff recover something on the basis of the best estimate possible, even if it is based on averages, than that she recover nothing."); King, supra note 5 , at 1385,1387 ("[ [] n spite of its unavoidable inexactness, the compensation of lost chances will introduce a substantial higher level of precision and, therefore, validity into the loss-assigning process."); see also Aagaard, 
Second, some commentators and jurists have argued that in order for lost chance theory to be viable, it is necessary to develop limiting principles that restrict its application. Such limitation is necessary, it is argued, so that lost chance theory does not lead to a mad rush to the courthouse and to an even more foreboding form of liability for employers, which may lead to unintended consequences, including more restrictive hiring and promotion practices. ${ }^{81}$ Although these concerns certainly have resonance, lost chance theory can be properly limited by applying a de minimis threshold. For instance, one possible limiting standard would be to restrict loss of chance recoveries to plaintiffs who had at least a $10 \%$ chance of receiving a job prior to the employer's discriminatory conduct. ${ }^{82}$ Such an approach would certainly address concerns regarding "flooding the courts with speculative cases." 83 In any event, the issue concerning whether there should be a de minimis exception to lost chance theory is separate from whether lost chance theory should be utilized at all. ${ }^{84}$ As Judge Posner wrote in Doll $v$. Brown in 1996:

supra note 49, at 1336; Truckor, supra note 17 , at 361 .

81. See Moore, supra note 13, at 214 (observing that some courts have limited the lost chance approach to cases of serious injury or death, or also requiring that the loss of a chance be substantial or significant); see also Doll, 75 F.3d at 1206 ("To avoid flooding the courts with speculative cases, the lost chance to be actionable should no doubt exceed a de minimis threshold.") (citations omitted).

82. There is nothing magical about the $10 \%$ threshold selected, although this number has heen found to be "substantial" as a matter of law by at least one court. See Pipe v. Hamilton, 56 P.3d 823, 829 (Kan. 2002). As the Supreme Court of Kansas stated in Pipe: "Pipe contends a 10 percent chance of survival is more than a trifling matter and is something that Kansas public policy supports as being recognized as substantial. We agree. As a matter of law, a 10 percent loss of chance cannot be said to be token or de minimis." Id.; see also Moore, supra note 13, at 214, 215 n.101 (noting that some courts have sought to limit the lost chance theory by requiring that the percentage lost be substantial or significant and recommending that courts specify a range of percentages that qualify as substantial). But see Perez, 805 P.2d at 592 (observing that a $10 \%$ loss of chance would probably not qualify as a substantial loss of chance under the doctrine).

83. Doll, 75 F.3d at 1206 . It may be said here that it is unlikely that such a mad rush to the courthouse would be caused by a pure loss of chance theory as the smallness of potential awards would not give individual plaintiffs enough incentive to pursue such awards. On the other hand, if a class action attorney brings a big enough class made up of plaintiffs each having less than a $1 \%$ chance of recovery, the incentive may be there for the lawyer to bring the claim if he can convince enough potential plaintiffs, and in particular a good lead plaintiff, to pursue the action. This latter scenario actually suggests that there should be a de minimis level of chance that must be exceeded before a case is considered appropriate for the lost chance approach.

84. See, e.g., Delaney, 873 P.2d at 185-86 (recognizing a lost chance theory of recovery, while at the same time disapproving of lost chance recovery for "token or de minimis" Iosses of chance). 
To avoid flooding the courts with speculative cases, the lost chance to be actionable should no doubt exceed a de minimis threshold . . . . But that is a detail which, important as it is for keeping the concept of the lost chance within reasonable bounds, does not qualify the essential soundness of the method. ${ }^{85}$

D.

The Herskovits Case: A Medical Malpractice Application of the Lost Chance Theory

The Supreme Court of Washington adopted the loss of a chance remedial approach in 1983 in the seminal case of Herskovits. ${ }^{86}$ In that case, the court was called on to decide whether an estate could maintain an action for professional negligence based on the failure to timely diagnose the decedent's lung cancer. ${ }^{87}$ As in the hypothetical example presented above, the estate could show that the defendants' negligence caused a decrease in the likelihood of the decedent surviving the cancer, but could not establish "but for" liability. ${ }^{88}$ Specifically, the misdiagnosis of the decedent's lung cancer caused a $14 \%$ percent reduction (from $39 \%$ to $25 \%$ ) in the chance of survival. ${ }^{89}$

In an interesting division of opinions, the supreme court, sitting en banc, ruled in favor of the plaintiff six to three. ${ }^{90}$ The lead opinion, in which only two justices joined, found that "medical testimony of a reduction of chance of survival from 39 percent to 25 percent is sufficient evidence to allow the proximate cause issue to go to the jury." 91 Thus, these two judges, following the so-called "increased

85. 75 F.3d at 1206 (citations omitted).

86. 664 P.2d at 486 (Pearson, J., concurring).

87. Id. (Pearson, J., concurring).

88. Id. (Pearson, J., concurring).

89. See id. at 475 (Pearson, J., concurring).

90. See id. at 479,487 (Pearson, J., concurring).

91. Id. at 479 (Pearson, J., concurring). It appears that the lead opinion is actually talking about cause-in-fact or factual cause (that is, "but for" cause), rather than proximate cause (that is, reasonable foreseeability). See Joseph H. King, Jr., "Reduction of Likelihood" Reformulation and Other Retrofitting of Loss-of-a-Chance Doctrine, 28 U. MEM. L. REV. 491, 498-99 (1998). Of course, Herskovits is not alone in falling into this confusion. See generally RESTATEMENT (THIRD) OF TORTS, supra note $9, \$ 26 \mathrm{cmt}$. a ("Both because it is not well-entrenched and because of the importance of distinguishing clearly between 'factual cause' and 'proximate cause,' this Restatement employs different terminology to address these two requirements for liability in tort."); Bert Black, $A$ New Metaphor for Clarifying the Difference Between Cause-in-Fact and Proximate Cause, 10 KAN. J.L. \& PUB. POL'Y 159 (2000) (discussing new methods for overcoming the general confusion between the tort concepts of cause-in-fact and proximate cause); see also Richard W. Wright, Causation in Tort Law, 73 CAL. L. REv. 1735, $1764 \mathrm{n} .121$ (1985) (maintaining that "confusion [between cause-in-fact and proximate cause] now pervades the fifth edition of Prosser's hornbook"). 
risk" approach, ${ }^{92}$ improperly conflated the causation and valuation inquiry as King predicted many courts would continue to do. ${ }^{93}$

Rather than defining the injury as a loss of a chance at survival, which the defendant clearly caused, ${ }^{94}$ the lead decision improperly defined the interest harmed in terms of the actual loss of decedent's life,${ }^{95}$ making it nearly impossible to establish that the defendants caused the decedent's harm. ${ }^{96}$ Nevertheless, the lead decision used the "increased risk" doctrine to resurrect the plaintiff's case. ${ }^{97}$ Stating that it is not for the "wrongdoer, who put the possibility of recovery beyond realization, to say afterward that the result was inevitable," opinion permits the issue of causation to go to the jury to determine whether the defendant's conduct deprived the plaintiff of a "significant" chance of recovery, and thereby allows the jury to make the step from increased risk to causation. ${ }^{99}$ Consequently, the lead decision in Herskovits speaks in the language of causation and does not even mention the separate concept of valuation or King's lost chance theory. ${ }^{100}$

92. Under the "increased risk" approach under section 323 of the Restatement (Second) of Torts, courts focus on defendants who have negligently rendered aid and consequently have increased the risk of harm to those they are trying to assist. See Herskovits, 664 P.2d at 476; see also Noah, supra note 2 (manuscript at 9) ("Some courts even apply the [loss of a chance] theory in cases where the ultimate injury has not yet-and may never-become manifest, which amounts to a claim for enhanced future risk.") (citing Andrew R. Klein, A Model for Enhanced Risk Recovery in Tort, 56 WASH. \& LEE L. REV. 1173 (1999)). Nevertheless, many look at increased risk cases with more skepticism in general than lost chance cases, arguing that a plaintiff should only bring such a case once the future harm actually materializes. See Aagaard, supra note 49, at 1343-44. Additionally, the comments to the new section 26 of the Restatement (Third) of Torts: Liability for Physical Harm, state that reliance on section 323 is misplaced in the lost chance context because "[section 323]'s placement in Topic 7, entitled 'Duties of Affirmative Action,' reveals that it addresses the question of the existence of a duty and its scope for a person who undertakes to protect another from harm." RESTATEMENT (THIRD) OF TORTS, supra note 9, § $26 \mathrm{cmt}$. $\mathrm{n}$.

93. See supra notes $36-39$ and accompanying text.

94. The parties stipulated for purposes of appeal that defendants "failed to diagnose [the decedent's] cancer on his first visit to the hospital and proximately caused [a] 14 percent reduction in his chances of survival." Herskovits, 664 P.2d at 475 .

95. "The ultimate question raised here is whether the relationship between the increased risk of harm and [the decedent's] death is sufficient to hold [defendant] responsible." Id. at 476 (emphasis added).

96. The parties had also stipulated that the decedent had less than a $50 \%$ chance of survival at all times. Id. at 475.

97. The approach of the majority is consistent with one of King's criticisms of the traditional all-or-nothing approach: it "creates pressure to manipulate and distort other rules affecting causation and damages in an attempt to mitigate perceived injustices." Id. at 487 (Pearson, J., concurring) (citing King, supra note 5, at 1377).

98. Id. at 476 (citations omitted).

99. Id. at 476,478 .

100. The lead opinion does use the terminology "loss of a chance." Id. at 478. 
On the other hand, the concurring opinion, written by Justice Vernon Pearson, and joined by three other justices, represents the first expressed endorsement of King's lost chance theory. ${ }^{101}$ First, the opinion, consistent with lost chance theory, defines the injury caused by the defendant as "the reduction of [the decedent's] chance of surviving the cancer from which he suffered." ${ }^{102}$ Second, having defined the injury differently, the concurring opinion also recognizes that "[w] hat caused a loss ... should be a separate question from what the nature and extent of the loss are." 103 Third, the concurrence concludes by stating that it "would hold that plaintiff has established a prima facie issue of proximate cause by producing testimony that defendant probably caused substantial reduction in [decedent's] chance of survival."104 Finally, and albeit in a footnote, the concurring opinion finds the statistics, showing a loss of a $14 \%$ chance of survival by the defendant's action, most appropriate for determining the amount of damages, rather than as a method of establishing causation. ${ }^{105}$

Interestingly, the Herskovits concurrence appears to adopt a modified lost chance theory. In reviewing cases cited by the plaintiff, Justice Pearson notes that three of the cases involve instances in which the chance of survival was greater than $50 \%$, and that in such cases the injury is properly recognized as the death of the decedent. ${ }^{106}$ That being said, the concurring opinion is not clear as to why it rejects King's "pure" version of lost chance theory, which would have instead required

However, it seems to be improperly conflating the increased risk doctrine with lost chance theory. See id. (Pearson, J., concurring). Whereas increased risk doctrine is still based on a causation inquiry and permits the jury to make "[t]he step from the increased risk to causation," id., (Pearson, J., concurring) lost chance theory focuses on redefining the interest harmed and then valuing that interest. See Aagaard, supra note 49, at 1344 ("Unlike the increased-risk claim, which seeks compensation for the possibility that an as-yet unmanifested injury will occur in the future, the harm in a lost chance case already has materialized.").

101. See Herskovits, 664 P.2d at 486 (Pearson, J., concurring) (explicitly stating that this conclusion to adopt lost chance theory was based on the "thoughtful discussion" of King).

102. See id. at 481 (Pearson, J., concurring).

103. Id. at 486 (Pearson, J., concurring) (quoting King, supra note 5, at 1363).

104. Id. at 487 (Pearson, J., concurring). Again, the concurrence confuses causation-in-fact with proximate cause. See supra note 92.

105. Id. at 475 ; id. at 487 n.2 (Pearson, J., concurring). As far as determining the amount of damages, Justice Vernon Pearson does no more than cite King's hypothetical lost chance calculation for guidance. See id. at 487 (Pearson, J., concurring) (citing King, supra note 5, at 1382). It is also interesting to note that permitting a $14 \%$ reduction in chance is consistent with setting the de minimis threshold at $10 \%$ as discussed above. See supra notes $82-85$ and accompanying text.

106. Herskovits, 664 P.2d at 485 (Pearson, J., concurring). 
lost chance theory principles to be applied across the board even to better-than-even-chance cases. ${ }^{107}$

In any event, after Herskovits, a number of courts adopted the lost chance theory in the medical malpractice context. ${ }^{108}$ Moreover, the lost chance theory has found some resonance among scholarly commentators and courts in such areas as wrongful life jurisprudence. ${ }^{109}$ That being said, almost all courts that have adopted lost chance analysis in the medical malpractice context have generally refused to extend it outside of those confines. ${ }^{110}$ Recently, however, the Seventh Circuit has sought to break that trend by introducing lost chance theory into the employment discrimination context.

\section{The INTROdUCTION OF "PuRE" Lost Chance THEORY INTO EMPLOYMENT DISCRIMINATION LITIGATION}

It would be another thirteen years after the Herskovits decision until lost chance theory would be applied to probabilistic injuries in the employment discrimination context. ${ }^{11}$ Judge Posner first suggested this approach in the case of Doll. ${ }^{112}$

107. See id. (Pearson, J., concurring).

108. See supra note 71.

109. See Greco v. United States, 893 P.2d 345, 348-50 (Nev. 1995) (utilizing the lost chance method to find for the plaintiff in a wrongful life case); Deana $A$. Pollard, Wrongful Analysis in Wrongful Life Jurisprudence, 55 ALA. L. REv. 327, 35658 (2004) (utilizing the lost chance doctrine in a wrongful life context to argue that a baby's loss of a chance at a healthier life constitutes a compensable injury).

110. See Noah, supra note 2 (manuscript at 10) (providing a list of the cases in which courts applied the lost chance theory to medical malpractice contexts); see also John C.P. Goldberg, What Clients Are Owed: Cautionary Observations on Lawyers and Loss of a Chance, 52 EMORY L.J. 1201, 1208-13 (2003) (arguing against expanding the lost chance theory into the legal malpractice context).

111. But see Paul Speaker, The Application of the Loss of Chance Doctrine in Class Actions, 21 REV. LITIG. 345, 354 (2002) (claiming that the lost chance doctrine had been previously applied to employment discrimination cases, but not referred to in those courts as "loss of a chance") (citing Hameed v. Int'l Ass'n of Bridge, Structural \& Ornamental Iron Workers, 637 F.2d 506 (8th Cir. 1980)). Yet, Hameed seems to be less about lost chance theory, and more about another theory of damage apportionment based on pro rata shares in the class action environment. See Hameed, 637 F.2d at 51921. In this regard, Hameed is a class-wide remedy case utilizing a one-size-fits-all "mathematical blender," see Kyriazi v. W. Elec. Co., 465 F. Supp. 1141, 1146 (D.N.J. 1979), rather than a case seeking to provide individual loss of chance determinations as the Seventh Circuit attempts to do in the three cases that follow. See infra Parts II.A-C.

112. 75 F.3d 1200. 


\section{A. Doll v. Brown: $A$ "Theoretical Discussion"13 on Pure Lost Chance Theory in the Employment Discrimination Context}

Charles Doll, a fifty-something electrician at a Veterans Administration hospital in Illinois, sued the U.S. government for disability discrimination and for failing to accommodate his disability under section 501 of the Rehabilitation Act of 1973. ${ }^{114}$ Specifically, Doll believed that because of a laryngectomy and tracheotomy stemming from throat cancer, he was forced to undertake a less desirable job (a parts and tool attendant) while he recovered, and was thereafter both refused reinstatement to his original electrician position and was not considered for a promotion to the electrical foreman position. ${ }^{115}$

After the federal district court found in Doll's favor at the conclusion of a bench trial, ${ }^{116}$ it reinstated him to his original, presickness electrician position. ${ }^{17}$ On the issue of whether he would have been further promoted to the electrical foreman position in the absence of discrimination, the district court sought to cobble together a remedial resolution based on the fact that it was unclear whether Doll would have actually received the foreman position. ${ }^{118}$ In this regard, the court awarded Doll over $\$ 61,000$ in back pay, ${ }^{119}$ and issued declaratory relief requiring that the Veterans hospital consider Doll for the electrician foreman position next time it became vacant. ${ }^{120}$

On appeal, Judge Posner, writing for a three judge panel of the Seventh Circuit, ${ }^{121}$ came to a rather unexceptional conclusion in vacating and remanding the district court's remedy. Finding that the case was a so-called "no-injury case," 122 the court focused on the nature of the

113. Bishop, 272 F.3d at 1016.

114. See 29 U.S.C. $\$ 791$; see also Doll, 75 F.3d at 1201 .

115. Doll, 75 F.3d at 1201-02.

116. Liability was found against the government on the basis of both disability discrimination and failure to accommodate the known physical disability of Charles Doll, a qualified applicant. Id. at 1203.

117. Id. at 1202.

118. Id. at 1205 (outlining Doll's counsel's argument that the district judge "split] the difference" in arriving at a remedy for Doll).

119. The back pay award "represent[edl the difference between the salary he actually received between April 1988 (when the foreman's job went to [the other applicant]) and the date of trial and the salary he would have received had he been made foreman then." Id. at 1202.

120. Id. As it turns out, the job became vacant during the litigation, but Doll was again passed over for the promotion. See id.

121. Id. at 1201. Judges Frank Easterbrook and John Cummings joined Judge Posner's decision for the court. Id.

122. In a "no-injury case," the plaintiff has proven liability and the defendant seeks to escape the imposition of damages by establishing by some burden of persuasion that tbe plaintiff was made no worse off by the discrimination. See id. at 1202 (citing Teamsters, 431 U.S. at 359, 362; Franks, 424 U.S. at 772-73). In contradistinction, 
burden that the defendant must meet in order to escape having to pay damages or any other forms of relief. ${ }^{123}$ Although Judge Posner was uncomfortable requiring defendants in no-injury cases to meet the clear and convincing burden of persuasion, the government defendant failed to properly brief the issue, and he, therefore, could make no ruling on this issue. ${ }^{124}$

On the other major point of contention involving the proper remedy for failing to promote Doll to the electrical foreman position, Judge

cases outside of the Title VII context may still fall under the Price Waterhouse $v$. Hopkins framework, meaning that the employer may still avoid liability by establishing that it would have taken the same decision even in the absence of discrimination. See Doll, 75 F.3d at 1202-03 (citing Price Waterhouse v. Hopkins, 490 U.S. 228, 242 (1989)). Since the enactment of the Civil Rights Act of 1991 ("the 1991 Act"), and its codification of mixed-motive analysis for Title VII cases, see 42 U.S.C. $\$ \S 2000 \mathrm{e}-2(\mathrm{~m})$, $2000 \mathrm{e}-5(\mathrm{~g})(2)(\mathrm{B})$, there is an argument that other types of discrimination cases (including disability cases under the Rehabilitation Act) should also be subject to the 1991 Act's analysis under which meeting this "same decision" test only goes to decreasing the types of damages available to a plaintiff, rather than relieving the plaintiff of all liability. See Doll, 75 F.3d at 1203 (assuming without deciding that Price Waterhouse still applies to some mixed-motive discrimination cases); see also 42 U.S.C. $\S 2000 \mathrm{e}-5(\mathrm{~g})(2)(\mathrm{B})$ (setting out the 1991 Act's approach to damages in Title VII mixed-motive cases); Miles F. Archer, Note, Mullin v. Raytheon Co.: The Threatened Vitality of Disparate Impact Under the ADEA, 52 ME. L. REv. 149, 156 n.56 (2000) (observing that it is still unclear whether the mixed-motive provisions of the 1991 Act apply outside of the Title VII context); Laura C. Marino, Note, A Necessary Tool: The Continuing Debate over the Viability of Disparate Impact Claims Under the Age Discrimination in Employment Act, 77 ST. JoHN's L. REV. 649, 654-55 n.33 (2003) (same). A more thorough discussion of the available remedies in non-Title VII, employment discrimination mixed-motive cases is beyond the scope of this Article.

123. See Doll, 75 F.3d at 1202. One of the significant ways in which constitutional and statutory torts in the employment discrimination context differ from the garden-variety medical malpractice or products liability tort is the availability of affirmative defenses to the defendant once the plaintiff carries her burden by proving that defendant has engaged in unlawful employment discrimination. See id. (citing Teamsters, 431 U.S. at 359, 362; and Franks, 424 U.S. at 772-73). Even if the plaintiff proves the employer has violated the law, the case does not end there. Instead, the burden of persuasion shifts to the employer to show that its actions made the employee no worse off; that is, the employer's actions caused the employee no injury. See id. In such a case, the defendant is not disclaiming liability, but seeking to reduce damages to a nominal level by arguing in essence that even though unlawful discrimination occurred, it did not cause any injury to the plaintiff. See id.

To those familiar with employment discrimination law, this shifting of the burden of persuasion is similar to what occurs with the "same decision" test in mixed-motive analysis, see 42 U.S.C. $\S 2000 \mathrm{e}-5(\mathrm{~g})(2)(\mathrm{B})$, or what occurs with the shifting of the burden of persuasion in the damages phase of Teamsters pattern and practice litigation. See 431 U.S. at 359 ("By 'demonstrating the existence of a discriminatory hiring pattern and practice' the plaintiffs had made out a prima facie case of discrimination against the individual class members; the burden therefore shifted to the employer 'to prove that individuals who reapply were not in fact victims of previous hiring discrimination." ) (quoting Franks, 424 U.S. at 772).

124. Doll, 75 F.3d at 1203-04, 1207. 
Posner was confused why the district court judge awarded full back pay to Doll, but nevertheless only ordered that he be considered for a promotion the next time the electrician foreman position became available. ${ }^{125}$ Instead, he thought that the district court should have either followed the traditional all-or-nothing approach and deny all relief to Doll, or it should have granted full relief, including full back pay along with either: (1) instatement into the electrical foreman position, or failing that, (2) front pay relief to place him in approximately the same position he would have been absent the discrimination. ${ }^{126}$ Because the district judge did not take either approach, Judge Posner vacated the back pay award and remanded the case back to the district court to determine the appropriate remedy for Doll. ${ }^{127}$

Nevertheless, because the district judge appeared to be torn between the fact that Doll was unlawfully discriminated against by the government in applying for the promotion to the foreman position, and the fact that the evidence suggested that Doll would probably not have received the foreman position even in the absence of discrimination, Judge Posner could not resist making another suggestion as to how the district judge could appropriately "split the difference" in fashioning a remedy for Doll. ${ }^{128}$ Although not required to do so in order to reach the holding in the case, ${ }^{129}$ Judge Posner suggested that the district court implement lost chance theory by applying the clear and convincing evidence rule governing the defendant's no-injury defense to "probabilities as distinct from certainties of loss." 130

The lost chance theory's focus on probabilities seemed to correspond perfectly with this type of employment discrimination case, where "proof of injury is inescapably uncertain." 131 After explaining the

125. See id. at 1205.

126. See id. ("[R]ather than just ordering the hospital to consider Doll for appointment to foreman the next time a vacancy arose, [hel should either have ordered him appointed to the position forthwith . . . or awarded him front pay ... . The relief he ordered fell short.").

127. See id. at 1207.

128. Id.

129. Indeed, the lost chance theory had been briefed by neither party, as Judge Posner candidly admits. See id. at 1206 (observing that, not only did the parties not raise the lost chance theory in this case, but neither had anyone else to his knowledge).

130. Id. at 1207.

131. Id. at 1205-06. As Judge Posner wrote: “[I]t strikes us as peculiarly appropriate in employment cases involving competitive promotion [to apply the lost chance theory]. In such a case the plaintiff's chances are inherently uncertain because of the competitive setting." Id. at 1206; see also King, supra note 91, at 495-96 (recognizing the lost chance doctrine's appropriateness in scenarios in which "it is proven that the defendant's active, tortious conduct probably caused the victim's materialized injury and the only question is to what extent to reduce damages for that injury to reflect the likelihood that the victim's preexisting condition would produce harm independent of the tortious conduct"). 
theory's origins in medical malpractice cases, ${ }^{132}$ Judge Posner expressed his opinion that the theory was "basically sound" and was merely "an extension of the routine practice in tort cases involving disabling injuries of discounting lost future earnings by the probability that the plaintiff would have been alive and working in each of the years for which damages are sought." 133 Relying upon King's seminal article, Judge Posner argued in Doll that what should be compensated in cases involving "the inescapably probabilistic character of many injuries" is not the loss of the job itself, but rather the loss of the opportunity to receive the job because of the employer's unlawful discriminatory conduct. ${ }^{134}$ Compensating plaintiffs on the loss of a chance to obtain a job was necessary in order to avoid undercompensation and underdeterrence, on one hand, or overcompensation and overdeterrence, on the other. ${ }^{135}$ And, even though Judge Posner recognized the somewhat arbitrary nature of saying that someone lost a $25 \%$ chance of obtaining a job, ${ }^{136}$ he nevertheless argued that such calculations would be no different from the calculations juries make all the time when they apportion fault under a comparative negligence statute. ${ }^{137}$

In the end, Judge Posner argued that doing these probability calculations front and center in order to split the difference in employment discrimination cases involving inherently uncertain injuries was far preferable to district court judges splitting the difference as they saw fit, perhaps based on nothing more than their own gut feelings. ${ }^{138}$ Nevertheless, recognizing that the application of lost chance theory to employment discrimination was an issue of first impression and had not

132. See Doll, 75 F.3d at 1205-06.

133. Id. at 1206. Put differently, Judge Posner's approach represents another application of the conjunction principle. See supra note 65.

134. See 75 F.3d at 1206 (emphasis added).

135. Id. To illustrate his point concerning the inefficient and unjust effects of an all-or-nothing approach in these types of employment discrimination cases, Judge Posner offered the following hypothetical in Doll:

Suppose there were five applicants for one job, the employer discrininated against four, and all four were equally well qualified, and the fifth got the job. Would all four of the discriminated-against applicants be entitled to back pay, one to the job, and the other three to front pay? Obviously not; yet without the lost-chance concept, which could grant reinstatement to none of the four and 25 percent front pay to each of them, the employer would get off scot-free.

Id.

136. Id. at 1206-07.

137. Id. at 1207. For a discussion of the criticisms surrounding the comparative negligence analogy, see supra note 77.

138. See Doll, 75 F.3d at 1206; see also supra note 79 (discussing the benefits of a transparent judicial decision-making process). 
yet been briefed, Judge Posner merely commended this theory in Doll to the bench and bar for further consideration. ${ }^{139}$

\section{B. Bishop v. Gainer: Cutting an Employment Discrimination Remedial "Gordian Knot"140}

It was not until about two years later that a district court judge took Judge Posner up on his invitation to apply the lost chance theory to an employment discrimination dispute. ${ }^{141}$ And, it was not until another three years later in 2001 that the Seventh Circuit sanctioned on appeal the district court's application of the lost chance theory for probabilistic injuries in the employment discrimination context. ${ }^{142}$

In Bishop, the Seventh Circuit considered whether the district court judge erred in applying the lost chance remedial theory to determine monetary damages awards for three prevailing plaintiffs who did not receive retroactive promotions in a reverse race discrimination case. ${ }^{143}$

139. See Doll, 75 F.3d at 1207.

140. This terminology was utilized by Judge Terence T. Evans in Bishop $v$. Gainer to describe the actions of the district judge, Judge Harry Leinenweber, in adopting a lost chance approach to a probabilistic injury scenario in the employment discrimination context. 272 F.3d at 1017. Although the reference to a "Gordian Knot" literally refers to "[a]n intricate knot tied by King Gordius of Phrygia and cut by Alexander the Great with his sword after hearing an oracle promise that whoever could undo it would be the next ruler of Asia," see American Heritage Dictionary of the ENGLISH LANGUAGE (4th ed. 2000), available at http://dictionary.reference. $\mathrm{com} / \mathrm{search}$ ?q=gordian\%20knot, it more figuratively refers to "an inextricable difficulty; and to cut the Gordian knot is to remove a difficulty by bold and energetic measures." See Datasegment.com Online Dictionary, at http://onlinedictionary. datasegment.com/word/gordian + knot (last visited June 26, 2005).

141. See Bishop, 272 F.3d at 1016. The case of Koski v. Gainer was initially filed against the Illinois State Police in May of 1992. See id. at 1011. In the case, different groups of white males alleged reverse discrimination under both 42 U.S.C. $\S$ 1983 ("Section 1983"), and Title VII, with regard to both hiring and promotion by the Illinois State Police. See Koski v. Gainer, No. 92-C-3293, 1999 WL 438910, at *1 (N.D. Ill. June 22, 1999). The promotion discrimination aspects of the case under Title VII appear to have been decided by the district court at a bench trial in 1998. See Bishop, 272 F.3d at 1011-12; see also Koski, 1999 WL 438910, at *1 (outlining the relief received by seven prevailing plaintiffs in the promotion part of the case).

142. See Bishop, 272 F.3d at 1016-17.

143. See id. at 1015. As this was a pattern and practice employment discrimination case involving systemic disparate treatment, well-established precedent under the Teamsters-Franks line of cases, see supra note 122, required the defendants to prove that each of the plaintiffs of the class was not entitled to relief because the plaintiff had already proven by the preponderance of the evidence that the defendant had engaged in an unlawful pattern and practice of employment discrimination. See Teamsters, 431 U.S. at 361. As the Court stated in Teamsters:

If an employer fails to rebut the inference that arises from the [plaintiff]'s prima facie case, a trial court may then conclude that a violation 
Each of these three prevailing plaintiffs objected to the application of the lost chance approach and argued that each of them should have been awarded the full value of the job for their unlawful discriminatory treatment. $^{144}$

In denying the plaintiffs their requested relief, Judge Terence $T$. Evans, writing for the Seventh Circuit majority, first noted that to award full compensation to all three plaintiffs, especially where two were competing for the same job, would not only be wrong, but "obviously wrong." 145 Harkening back to the hypothetical offered by Judge Posner in Doll involving multiple candidates for a single promotion, ${ }^{146}$ the Bishop court maintained that the traditional all-or-nothing approach to situations such as these would inevitably lead to windfall recoveries for plaintiffs. ${ }^{147}$ Instead, the appellate court agreed with the district court in using the "tort approach" based on the loss of a chance. ${ }^{148}$

Under this approach, the district court calculated the plaintiffs' damages by assessing their chances of receiving the competitive promotion in the absence of discrimination. ${ }^{149}$ For instance, two of the three plaintiffs placed third and fourth respectively on a promotion list, but the person who placed first accepted a different job, and the person who placed second had been out of the particular district, and therefore, the court reduced his chances of actually accepting the promotion to only $25 \% .{ }^{150}$ Although not fully explaining how he arrived at his numbers, the district judge found that the plaintiffs who placed third and fourth on the promotion had a $45 \%$ chance and $30 \%$ chance of receiving

has occurred and determine the appropriate remedy. Without any further evidence from the [plaintiff], a court's finding of a pattern or practice justifies an award of prospective relief.

Id.

144. See Bishop, 272 F.3d at 1015. Nothing in the Teamsters decision, however, suggests that the relief awarded to individual plaintiffs within a group or class must be "full" relief. See generally 431 U.S. 324. Indeed, the Teamster Court observed that a trial court must hold mini-hearings in the damage phase of these cases in order to award appropriate relief to each memher of the class. See id. at 361 ("When the [class] seeks individual relief for the victims of the discriminatory practice, a district court must usually conduct additional proceedings after the liability phase of the trial to determine the scope of individual relief.").

145. See Bishop, 272 F.3d at 1015-16. As the Bishop court stated: "What plaintiffs are really complaining about is that they did not each make a full recovery, which, as we shall see, at least in the case of [two of the plaintiffs], would have caused the [Illinois State Police] to pay double damages. 'Obviously' not the right result."

146. See supra note 135.

147. Bishop, 272 F.3d at 1016.

148. Id.

149. Id.

150. Id. 
the promotion, respectively, and thus, were entitled to only that percentage of the value of the job. ${ }^{151}$

While the appellate court recognized that lost chance theory involved "more art than science," 152 it nevertheless approved the theory for these types of employment discrimination cases, finding that similar types of calculations are made all the time in other contexts, such as in comparative negligence cases. ${ }^{153}$ Perhaps more importantly, the use of lost chance theory in this context struck the court as the "likeliest way to arrive at a just result," and thus, it fully affirmed the lost chance calculations of the district court. ${ }^{154}$

\section{Biondo v. City of Chicago: Applying Lost Chance Theory to Speculative Future Promotions}

Since Doll, and in fact even since Bishop, there has been only a smattering of cases that have applied the lost chance theory to employment discrimination cases. ${ }^{155}$ Indeed, the author was only able to find two such cases outside of the Seventh Circuit. ${ }^{156}$ Nevertheless, as

151. Id.

152. Id.

153. Id. at 1016-17; see also supra note 77 .

154. Bishop, 272 F.3d at 1017.

155. Drews v. Social Dev. Comm., 95 F. Supp. 2d 985, 989 (E.D. Wis. 1998) (awarding the plaintiff $12.5 \%$ of salary and fringe benefits for a better job for which eight others also applied); Farley v. Miller Fluid Power Corp., No. 94-C-2273, 1997 WL 757863, at *3 (N.D. Ill. Nov. 24, 1997) (denying a motion in limine to exclude all evidence of the plaintiff's alleged lost chance of promotion); Adams v. City of Chicago, No. 94-C-5727, 1996 WL 137660, at *19 (N.D. Ill. Mar. 25, 1996) (concluding that the plaintiffs' argument, that retroactive promotions are not a plausible remedy for the injury of denial of an opportunity to compete for a promotion, is not likely to succeed because of the availability of the lost chance theory); $c f$. Liebig-Grigsby v. United States, No. 00-C-4922, 2003 WL 1090272, at *14-15 (N.D. Ill. Mar. 11, 2003) (finding that, when a government employer refused to refer an employee to a neurosurgeon and the employee lost a $70 \%$ to $80 \%$ chance of halting further deterioration of her spinal cord as a result, the employee was entitled to the same percentage of the total damage award).

156. See Evans v. Potter, 215 F.R.D. 571, 574 (D.S.D. 2003) (applying a mandatory joinder analysis under Rule 19 of the Federal Rules of Civil Procedure); Alhright v. New Orleans, 208 F. Supp. 2d 634, 640-41 (E.D. La. 2002) (relying on expert testimony to establish the value of the lost promotion to each plaintiff, and then multiplied the promotion value by the probability that each plaintiff would have received the promotion). The court in Evans brought up the interesting question of what to do when three individuals are denied a promotion in an allegedly unlawfully discriminatory manner, but only one of these individuals has actually brought a claim. See 215 F.R.D. at 574. It noted that, if it awarded the plaintiff full recovery, such an award might lead to inconsistent obligations on the defendant if other courts later found for the other two individuals who applied for the same job. See id. As such, using Rule 19 of the Federal Rules of Civil Procedure, defendants sought mandatory joinder of the other potential plaintiffs as necessary parties. See id. (requiring "'a substantial risk' of inconsistent or 
witnessed by the Seventh Circuit's recent decision in Biondo, ${ }^{157}$ the Seventh Circuit remains steadfast in applying the lost chance theory to probabilistic injuries in employment discrimination cases, even when such cases involve speculative future promotions.

In Biondo, nineteen firefighters and engineers sued the City of Chicago under 42 U.S.C. § 1983 ("Section 1983") and Title VII for reverse race discrimination when they were not promoted to the rank of lieutenant after taking a competitive promotion examination in $1986 .{ }^{158}$ They alleged that the City of Chicago had maintained racially segregated promotion lists, and that in the absence of these lists, they would have been promoted to lieutenant. ${ }^{159}$ Moreover, these plaintiffs maintained that there was some likelihood that after becoming lieutenants, they would have sought further promotions to the rank of captain and battalion chief. ${ }^{160}$ After finding in the plaintiffs' favor, the district court ordered various forms of injunctive relief and utilized the lost chance method to determine the value of the probabilistic injuries each of these firefighters and engineers suffered. ${ }^{161}$

Although neither the parties nor the Seventh Circuit quarreled with the central approach of the district court in using the lost chance theory to determine the value of these probabilistic injuries, some of the results arrived at by the juries ${ }^{162}$ were baffling. ${ }^{163}$ Consequently, Judge Frank Easterbrook, writing for the appellate panel, reevaluated the evidence on his way to vacating the damage award with instructions for the district court to follow on remand. ${ }^{164}$

First, Judge Easterbrook pointed out that all of the plaintiffs should receive $100 \%$ of the value of the lieutenant promotions, retroactive to when they would have received the promotion in the absence of the

multiple obligations before joinder is necessary") (citing FED. R. Clv. P. 19(a)(2)(ii)). In the end, the court ordered joinder of the other potential plaintiffs in order to avoid posing inconsistent obligations on the defendant. See id. Unfortunately, there is no further published history of this case concerning what happened after the mandatory joinder was required.

157. 382 F.3d 680.

158. 382 F.3d at $682-83$.

159. Id. at 683 .

160. Id. at 684-85.

161. Id. at 688 . As the court stated: "The City does not dispute the district court's central approach: asking the jury to determine the probability that being held back in 1986 cost the plaintiffs later chances for advancement. This 'loss of a chance' method is the best way to handle probabilistic injuries." Id.

162. Two different juries actually heard the case. See $i d$. at 683,685 .

163. For instance, with respect to one of the plaintiffs, the jury determined that he had a $90 \%$ chance of becoming a captain and a $100 \%$ chance of becoming a battalion chief, even though one must become a captain before they are eligible for the battalion chief position. See id. at 688.

164. See id. at 690-92. 
discriminatory selection method. ${ }^{165}$ Unlike a situation in which there are multiple candidates for just one position, ${ }^{166}$ this case provided an example in which the first promotion was never in doubt in the absence of the racially segregated selection test; but, it was unclear whether, and how successful, these same firefighters and engineers would have been if they applied for later promotions to the captain and thereafter, to the battalion chief positions. ${ }^{167}$ Judge Easterbrook estimated that promoted lieutenants in the Chicago Fire Department had about a 33\% chance of subsequently attaining the captain position. ${ }^{168} \mathrm{He}$ also calculated that once becoming a captain, firefighters had a $41 \%$ chance of then becoming a battalion chief. ${ }^{169}$ As a result, he calculated the chance of rising from the lieutenant position to the battalion chief position at 14\%. ${ }^{170}$ Overall, Judge Easterbrook concluded his damage calculation

165. Because there were enough positions available for all plaintiffs to receive promotions to the lieutenant position, and all would have been promoted absent the use of racially discriminatory selection criteria, each plaintiff had a $100 \%$ chance of receiving the promotion absent discrimination. See id. at 688 (" [I]f a person would have had a $25 \%$ chance of promotion from lieutenant to captain, then preventing that person from becoming a lieutenant should lead to a remedy equal to $100 \%$ of the benefits of being a lieutenant plus $25 \%$ of the incremental benefits of being a captain."). Judge Easterbrook observed, however, that this calculation will only hold true if we are to assume that all of the plaintiffs are risk neutral. See id. Although he admits that such plaintiffs would likely be risk averse and pay to reduce the risk (so that the proper award should be something less than the actuarial value), for simplicity sake he continues on with his risk neutral assumption. See id.

166. This was the case in both Bishop and Doll. See supra Part II.A-B.

167. Biondo, 382 F.3d. at 690 . Additionally, the plaintiffs made their lost chance showing more difficult by failing to provide comparative evidence of how similarly situated white firefighters and engineers who were promoted to lieutenant subsequently fared on later the captain and battalion chief competitive examinations. Id. at 689. Instead, the plaintiffs merely adduced evidence about their education and experience and the fact that they loved their work, were committed to the fire department, strived to succeed, and studied hard for the promotion tests. Id. Judge Easterbrook found that this evidence, however, did not permit the quantification of the chance lost by not being initially promoted in 1986. Id. Although I agree with Judge Easterbrook concerning most of this evidence, testimony concerning education and experience can be helpful in quantifying the chance a discriminated-against plaintiff had in obtaining a desired position. See infra Part IV.B.2.

168. Biondo, 382 F.3d at 690 . Judge Easterbrook appeared to be following the analytical framework established by the U.S. Court of Appeals for the Sixth Circuit in Griffin v. Michigan Department of Corrections in which the court stated that, "[i]n an ideal situation, where the data is available and the parties cooperative, a court could determine what would be the progression of an average worker with the basic qualifications possessed by the injured party." 5 F.3d 186, 189 (6th Cir. 1993). Moreover, "[t]he burden of proof would then be on the defendant to prove that the plaintiff would have performed more poorly than the average and the burden of proof would be on the plaintiff to show that she would have performed better than that average." Id.

169. Biondo, 382 F.3d at 690.

170. The I4\% figure is arrived at by applying the conjunction principle and 
by stating that "[o]n remand each of the 13 [plaintiffs who have stopped short of captain] is entitled to all of the benefits he would have received from a timely promotion to lieutenant, plus $33 \%$ of the benefits available from promotion to captain." 171 Additionally, for the ten plaintiffs who the jury believed had a chance of achieving the battalion chief level, they would receive an additional $14 \%$ of the value of the battalion chief position benefits. ${ }^{172}$

Thus, Biondo represents yet another example of how the lost chance method may be utilized to determine difficult remedial issues. ${ }^{173}$ But, unlike the Doll and Bishop decisions, which involved only the determination of the probability of multiple candidates receiving a promotion for one available job, Biondo provides a future promotions scenario with the additional complication of determining the future career paths of many plaintiffs who have been denied advancement in the midst of their careers. ${ }^{174}$ Although the "average worker" followed by Judge Easterbrook ${ }^{175}$ in Biondo is less than perfect, especially in the absence of specific comparative evidence, its calculations nevertheless appear to provide a skilled approximation of the probabilistic injuries suffered by these types of plaintiffs. ${ }^{176}$

multiplying the initial chance of becoming a captain (33\%) by the subsequent chance of becoming a battalion chief (41\%). See id.; see also supra note 65 . Again, being able to recover for a $14 \%$ loss of chance (as in Herskovits) is consistent with the $10 \%$ de minimis threshold argued for in this Article. See supra notes 82-85 and accompanying text.

171. Biondo, 382 F.3d at 690.

172. See id. Moreover, because "[a] change in the promotion probabilities and dates requires everything else to be redone," Judge Easterbrook also instructed the district court on remand to recalculate the equitable remedies (including back pay, front pay, and entitlement to seniority and pensions), and hold a new trial limited to the recalculation of "back pay and damages for emotional distress on the assumption that each of the plaintiffs who has yet to reach captain lost a $33 \%$ chance of promotion by 2002." Id. But see infra note 240 (asserting that lost chance analysis should not be part of the compensatory damage analysis undertaken by the jury in an employment discrimination case).

173. See Biondo, 382 F.3d. at 690 (using the lost chance method to determine damages). But see United States v. City of Miami, 195 F.3d 1292, 1300-02 (11th Cir. 1999) (addressing a similar promotion case in which the court avoided a quagmire of hypothetical judgments associated with the lost chance theory and instead awarded a class-wide remedy, giving each eligible plaintiff in each ranking level a pro rata share).

174. See Griffin, 5 F.3d at 189 (discussing the difficulty of determining the appropriate relief in cases in which an initial unlawful discriminatory employment action may cost the plaintiff chances for later career advancement).

175. Biondo, 382 F.3d at 690 . The "average worker" approach was actually first suggested by Judge Danny Boggs of the Sixth Circuit in Griffin. See 5 F.3d at 189.

176. As will be discussed below, the ideal situation for lost chance analysis in the employment discrimination context would permit a fact finder to engage in individual fact-finding to approximate as closely as possible the chance the individual had to obtain a position prior to the discrimination. See infra notes 231-38 and accompanying text. The "average worker" test, however, may be useful in cases like Biondo as a substitute 


\section{CONSIDERATIONS ADVISING AGAINST ADOPTING PURE LOST CHANCE THEORY IN EMPLOYMENT DISCRIMINATION CASES}

Although Doll involved language contemplating the utilization of a pure version of lost chance theory in the employment discrimination context, ${ }^{177}$ neither Bishop nor Biondo consider the efficacy of pure lost chance theory in this context. ${ }^{178}$ Consequently, it is necessary to consider whether courts in the future should adopt a pure lost chance theory to calculate the value of probabilistic injuries in the employment discrimination context. This Article posits that the adoption of such an approach would be inappropriate for two primary reasons. First, from a statutory standpoint, pure lost chance theory primarily satisfies the private, "make whole" relief goal of employment discrimination law, while failing to give sufficient attention to the public interests that such laws are also intended to serve. Second, from a prudential standpoint, the pure version of lost chance gives zealous defense counsel an additional opportunity to confuse the remedial issues for the fact finder, and by extension, may significantly add to the administrative costs associated with the litigation of such disputes. ${ }^{179}$

\section{A. Statutory Concerns Regarding Pure Lost Chance Theory}

Although allowing defendant employers the ability to set off employment discrimination awards by the probability that the plaintiff would have received the job in better-than-even-chance cases appears to be a logical extension of themes underlying lost chance theory, ${ }^{180}$ under closer scrutiny, it is not compatible with one of the central purposes of

when there are no suitable individual comparators, or in class action situations in which it would be too expensive and time consuming to engage in mini-hearings to determine the exact loss of chance suffered by each member of a voluminous class. See ROBERT Belton \& Dianne Avery, Employment Discrimination law: Cases and Materials ON EQUALITY IN THE WORKPLACE 795-96 (6th ed. 1999).

177. See supra Part II.A.

178. This is because neither Bishop nor Biondo involved fact scenarios in which the plaintiffs had more than a $50 \%$ chance of receiving a promotion, as Doll speculated might be the situation in some circumstances. See Doll, 75 F.3d at 1206.

179. See Ellis, supra note 23, at 372. As Lori Ellis wrote:

It seems likely that in jurisdictions that have already adopted loss of chance for cases below fifty-one percent, the defense bar may advocate extending loss of chance to better-than-even cases in an effort to limit damages to the value of the 'lost chance' rather than full damages for wrongful death.

Id.

180. See King, supra note 5, at 1387 (advocating the application of lost chance theory to better-than-even-chance cases); see also EPSTEIN, supra note 66, at 253 (advocating the adoption of a pure form of lost chance theory in the tort context to avoid systematic overcompensation of plaintiffs and overdeterrence of defendants). 
employment discrimination law. ${ }^{181}$ As discussed above, Title VII and other similar employment discrimination laws were enacted by Congress not only to provide a private remedy for those unlawfully discriminated against, but also, and perhaps most importantly, to serve the public goal of eliminating unlawful discrimination from the American economy. ${ }^{182}$ In order to take into account both the private and the public statutory purposes of employment discrimination laws, courts should be able to overcompensate plaintiffs with "punitive-type" equitable relief in cases in which a better-than-even chance of proving discrimination has been established in order to satisfy the larger public interest goals of employment discrimination law. ${ }^{183}$

Punitive-type equitable relief does not mean the traditional monetary punitive damages that have been available for intentional discrimination under Title VII since Congress enacted the Civil Rights Act of 1991 ("1991 Act"). ${ }^{184}$ Rather, punitive-type equitable relief in

181. See Albemarle Paper, 422 U.S. at 421 (establishing eradication of discrimination throughout the economy as one of the central statutory purposes of Title VII).

I82. See Waffle House, 534 U.S. at 292; United Steelworkers of Am. v. Weber, 443 U.S. 193, 204 (1979) (discussing the broad public purposes of Title VII in the voluntary affirmative action context); Franks, 424 U.S. at 771; Albemarle Paper, 422 U.S. at $42 \mathrm{I}$.

183. See Franks, 424 U.S. at 764 (“[F]ederal courts are empowered to fashion such relief as the particular circumstances of a case may require to effect restitution, making whole insofar as possible the victims of racial discrimination in hiring."); see also Waffle House, 534 U.S. at 294-95 (2002) ("[W]hile punitive damages benefit the individual employee, they also serve an obvious public function in deterring future violations."). This approach for providing punitive-like equitable relief in lost chance cases in the employment discrimination context should be viewed as consistent with Professors A. Mitchell Polinsky and Steven Shavell's basic point that punitive damages make sense from a deterrence standpoint "if, and only if, an injurer has a chance of escaping liability for the harm he causes." See A. Mitchell Polinsky \& Steven Shavell, Punitive Damages: An Economic Analysis, 11 I HARv. L. REv. 869, 874 (I998). Here, unless we utilize punitive-type equitable relief, there is a significant chance that the public-regarding aspects of employment discrimination law will go unfulfilled. See id. at 939-40 (suggesting that, although foreseeing some problems, "if there is a component of harm that otherwise would be omitted, a policy of including it in the form of punitive damages would seem to be beneficial"). And, although Polinsky and Shavell refer to these monetary awards as "damages," and this Article refers to them as "equitable relief," the distinction is really semantic if at the end of the day the plaintiff is compensated monetarily for the violation of the public interest caused by the employer's wrongful conduct.

184. See 42 U.S.C. $§ 1981$ a. Under the $1991 \mathrm{Act}$, it is now clearly established that punitive damages are available in Title VII and the ADA cases in which an employer has engaged in "discriminatory practices with malice or with reckless indifference to the federally protected rights of an aggrieved individual." $I d$. $\S$ 1981a(b)(1). The Supreme Court has further elucidated this standard in Kolstad $v$. American Dental Ass'n by focusing on whether an employer discriminated against an employee in the face of a perceived risk that its actions would violate federal law. 527 
this sense constitutes a remedy that a court may deem appropriate in order to effectuate the purposes of the statute. ${ }^{185}$ In this regard, this relief will serve not so much to "punish" a specific employer for particularly egregious conduct, ${ }^{186}$ but more to satisfy the broader statutory mandate of deterring all employers throughout the economy from engaging in unlawful employment discrimination.

Clearly, individual plaintiffs in better-than-even-chance cases will not object if they receive the full value of the job they have more likely than not lost through unlawful discrimination. Employers, on the other hand, will maintain that they should be on the hook only for the damage they actually caused. ${ }^{187}$ There are at least three responses to these employers. First, to the extent that the employer has discriminated and has made it impossible to determine the exact chance a plaintiff would have had to obtain the position in the absence of discrimination, he should not now be permitted to use that uncertainty as a legal sword to

U.S. 526, 536 (1999). Moreover, in this context, punitive damages cannot be imputed to the employer if the employer can prove that the employment decisions of its managerial agents were contrary to its good-faith efforts to comply with TitIe VII. See id. at 545 .

185. See 42 U.S.C. $\S 2000 \mathrm{e}-5(\mathrm{~g})(1)$ (" $[\mathrm{T}]$ he court may . . . order . . . any other equitable relief as the court deems appropriate."); see also Franks, 424 U.S. at 770 ("The fashioning of appropriate remedies invokes the sound equitable discretion of the district courts."). This broad equitable power is believed to have been based upon similar language in the National Labor Relations Act ("NLRA"), which permits the National Labor Relations Board to "take such affirmative action .... as will effectuate the policies of [the] NLRA." 29 U.S.C. $\S 160$ (c); see also Franks, 424 U.S. at 769 n.29 "To the extent that there is a difference in the wording of the respective provisions, $\S 706(\mathrm{~g})$ grants, if anything, broader discretionary powers than those granted the National Labor Relations Board.").

186. It is generally agreed that one of the central purposes of punitive damages is to punish an employer for especially outrageous conduct on the employer's part. See State Farm Mut. Auto. Ins. Co. v. Campbell, 538 U.S. 408, 419 (2003); see also Polinsky \& Shavell, supra note 183, at 948 ("By the punishment objective [of punitive damages] we refer to society's goal of imposing appropriate sanctions on blameworthy parties.").

187. See Scafidi v. Seiler, 574 A.2d 398, 408 (N.J. 1990) ("It should be a selfevident principle of tort law that valuation of allowable damages 'is animated by a premise similar to that underlying causation: that a tortfeasor should be charged only with the value of the interest he destroyed.'") (quoting King, supra note 5, at 1356). Such an argument is also consistent with an efficiency argument under a law and economics approach. See Michael Ashley Stein, The Law and Economics of Disability Accommodations, 53 DUKE L.J. 79, 119, 124 (2003); see also Saul Levmore, Probabilistic Recoveries, Restitution, and Recurring Wrongs, 19 J. LEGAL STUD. 691, 692 (1990) ("The legal system is viewed as aiming to transfer payments from wrongdoers to the victims they harm, and deviations from this norm are regarded as errors."); Polinsky \& Shavell, supra note 183, at 939 ("[O]ur basic analysis of deterrence implies that injurers should have to pay for the entire harm they cause, in order that injurers take appropriate precautions and that prices and participation in risky activities are proper."). 
reduce his damage exposure. ${ }^{188}$ If anything, such employers should have to suffer from the uncertainty caused by their unlawful conduct, not the wronged plaintiff. ${ }^{189}$

Second, the Supreme Court has again and again emphasized the prophylactic purposes of employment discrimination law. ${ }^{190}$ Employment discrimination law is not just about compensating victims, or even deterring employer conduct, but rather seeks to give employers the incentive to take preventative steps to make the workplace more welcoming to all. ${ }^{191}$ Thus, if an employer reasonably seeks to prevent sexual harassment in the workplace, and the employee unreasonably fails to take advantage of such preventative opportunities or otherwise fails to avoid harm, the employer has an affirmative defense against vicarious liability in such cases. ${ }^{192}$ Similarly, in the punitive damages context, if the employer attempts in good faith to follow the dictates of Title VII, whatever the egregiousness of the supervisor's conduct, the employer will not be found liable for punitive damages. ${ }^{193}$ Likewise, an award of full equitable relief in these better-than-even-chance cases can be seen as an additional incentive for employers to take preventative action before misconduct diminishes an opportunity for hiring or advancement in the workplace. ${ }^{194}$

Third, perhaps the best argument is that the lost chance doctrine should never apply in a better-than-even-chance case. ${ }^{195}$ As courts and commentators alike have argued, once a plaintiff is able to show, by the preponderance of the evidence, that it is more likely than not that the defendant caused her ultimate injury, there is no need to identify the

188. See GREEN, supra note 2, at 3 ("When defendants bear responsibility for the gap in evidence, the case is especially strong [to relax the preponderance thresholdl."); see also United States v. City of Warren, 138 F.3d 1083, 1098-99 (6th Cir. 1998) (finding that the district court did not abuse its discretion when it refused to consider the probability of the plaintiff being hired and instead construed ambiguities against the employer); Trout v. Garrett, 780 F. Supp. 1396, 1406-07 (D.D.C. 1991) (finding that, because the defendant was unable to show how many promotions were available, ambiguities were resolved against the employer and each plaintiff was awarded full back pay as if they had received the promotion).

189. See King, supra note 5, at 1378. A similar argument has been made for shifting accident costs to manufacturers under a strict liability theory in the products liability context. See James A. Henderson, Jr., Coping with the Time Dimension in Products Liability, 69 CAL. L. REv. 919, 931-32 (1981).

190. See Kolstad, 527 U.S. at 545 ("[Title VII]'s 'primary objective' is 'a prophylactic one,' it aims, chiefly, 'not to provide redress but to avoid harm.'”) (quoting Faragher, 524 U.S. at 805-06; and Albemarle Paper, 422 U.S. at 417).

191. See Faragher, 524 U.S. at 806.

192. See id. at 806-07; Burlington Indus., 524 U.S. at 762-63.

193. See Kolstad, 527 U.S. at 545.

194. See supra note 191 and accompanying text.

195. See Ellis, supra note 23 , at 372. 
harm as the loss of the opportunity. ${ }^{196}$ In other words, loss of chance doctrine only provides for a percentage of damages based on the probability of a favorable outcome in the absence of the defendant's unlawful conduct. But, if a plaintiff under the traditional all-or-nothing approach can establish that it is more likely than not that the wrongdoer caused the ultimate harm, there is no need to depend on the subsidiary theory and its lesser compensations. ${ }^{197}$

Thus, both traditional causation standards and the public nature of employment discrimination statutes support a modified approach to lost chance theory in the employment discrimination context. To the extent overcompensation is argued to result as a consequence of this remedial scheme, ${ }^{198}$ such additional compensation should be seen as an equitable remedy necessary to effectuate the broader public deterrence purposes of employment discrimination statutes. ${ }^{199}$

\section{B. Prudential Concerns Regarding Pure Lost Chance Theory}

In addition to the important statutory concerns regarding the publicoriented nature of employment discrimination law, further prudential considerations counsel against adopting the pure lost chance theory in the employment discrimination context. These prudential concerns can be grouped into two main areas.

First, and chief among these concerns, are the perverse incentives

196. See id.; see also Donnini v. Ouano, 810 P.2d 1163, 1168 (Kan. Ct. App. 1991) (limiting the application of lost chance theory to not-better-than-even-chance cases). But see Kieffer, supra note 9, at 573 (arguing that not applying lost chance to better-than-even-chance cases is inconsistent with current efforts to curb perceived excesses of the tort system).

197. See Ellis, supra note 23 , at 372 ("[Loss of chance] should be understood as a 'technique[ for mitigating the perceived injustice' of granting summary judgments or directed verdicts to all doctors who act negligently toward patients with a not-betterthan-even chance of survival.") (quoting DAvid W. ROBERTSON ET AL., CASES AND MATERIALS ON TORTS 157 (1989)); see also McMullen v. Ohio State Univ. Hosps., 725 N.E.2d 1117, 1122 (Ohio 2000) ("[W]e never intended to force [the lost chance] theory on a plaintiff who could otherwise prove that specific negligent acts of the defendant caused the ultimate harm."); Noah, supra note 2 (manuscript at 34) (suggesting that the only type of case in which the "novel" loss of a chance claim makes sense is where patients had a chance of survival of less than $50 \%$ even in the absence of negligence).

198. See Doll, 75 F.3d at 1206 ("[T]hough to avoid the opposite evils of overcompensation and overdeterrence [lost chancel... must be applied across the board, that is, to high-probability as well as to low-probability [employment discrimination] cases."). Judge Posner's pure lost approacb is consistent with a law and economics precept favored in all types of proportional liability cases; that is "the central idea ... that a defendant should pay for damages incurred discounted by the probability that the defendant caused the damages." GREEN, supra note 2, at $9 \mathrm{n} .22$; see also Makdisi, supra note 2, at 1073.

199. See supra notes $184-89$ and accompanying text. 
that defense counsel will have to confuse and mislead the judge or jury ${ }^{200}$ to reduce the amount of her client's liability. ${ }^{201}$ Such incentives will inevitably occur because almost no plaintiff in a competitive hiring or promotion case will be able to prove that she had an absolute, $100 \%$ chance of receiving a position. ${ }^{202}$ A loss of a chance argument will normally be available to defense counsel to argue that in the absence of discrimination, there were many other reasons why the employee did not receive the position. ${ }^{203}$ Consequently, the record of these cases will be further clouded as various forms of complex evidence are adduced to approximate the exact chance a plaintiff had of receiving a job. ${ }^{204}$

Second, the additional administrative costs introduced into these types of employment discrimination cases by way of the pure lost chance theory must be considered. Law and economics scholars refer to administrative costs as "the legal and other expenses and costs [including time and effort] borne by parties in resolving disputes that arise when harm occurs." ${ }^{205}$ There is little doubt that the added complexity of lost chance theory will exacerbate to some degree the administrative costs associated with litigation. ${ }^{206}$ Parties will likely seek

200. It is more likely that judges will make lost chance calculations in employment discrimination cases because they determine equitable remedies such as back pay and front pay. See, e.g., Bishop, 272 F.3d at 1015 (calculating the equitable remedies in a pattern and practice employment discrimination case). But see Biondo, 382 F.3d at 688 (addressing a case in which lost chance calculations in an employment discrimination case led to "inexplicable verdict[s]" concerning certain members of the class). To the extent that judges rather than juries resolve these issues, it may be harder for defense counsel to confuse more sophisticated jurists with this type of evidence and the concomitant calculations. But see infra note 207.

201. See Truckor, supra note 17 , at 365.

202. See GREEN, supra note 2, at 5 ("Evidence is never perfect; uncertainty always exists.").

203. A similar defense exists for employers under the "same decision" test in mixed-motive cases under Title VII. See 42 U.S.C. $\$ 2000 \mathrm{e}-5(\mathrm{~g})(2)(\mathrm{B})$.

204. See Truckor, supra note 17 , at 365 . Although one can make the argument that defendants in traditional tort cases also seek to cloud the record to benefit their clients in marginal cases (that is, cases in which it is a close call as to whether traditional causation can be proven by a preponderance of the evidence), there is certainly less reason why we should encourage defense counsel to engage in this tactic in cases where meeting the preponderance standard is never in doubt (that is, where the only question is whether it was $95 \%$ likely that the defendant caused the plaintiff's injury versus $90 \%$ likely).

205. Steven Shavell, Foundations of Economic analysis of LaW 57 (2004). More specifically, administrative considerations include the volume of suits, the probability of litigation given suit, and the average expense of litigation. See Steven Shavell, Uncertainty over Causation and the Determination of Civil Liability, 28 J.L. \& ECON. 587, 604 (1985).

206. See Shavell, supra note 205 , at 604 ("[A]dministrative costs would be higher under the proportional approach than under a probability threshold criterion."). 
to present dueling experts and adduce intricate evidence concerning the probability of an individual receiving a particular position. ${ }^{207}$

However, to the extent that these lost chance awards are limited to equitable relief such as back pay, reinstatement, and front pay, judges will be the ones considering statistical evidence and dueling experts. ${ }^{208}$ Although by no means error-proof, judges will be more likely to minimize the additional administrative costs this type of evidence will no doubt cause. Recent case law suggests, however, that juries will be involved in these lost chance calculations in employment discrimination cases as these damages may not only involve equitable relief, but also emotional distress damages, and potentially, punitive damages. ${ }^{209}$ Compensatory and punitive damages are remedial issues that a plaintiff may decide to have a jury determine under the 1991 Act. ${ }^{210}$ Given this fact, the minimization of administrative costs through the use of judges in these cases is somewhat questionable.

In short, prudential considerations also counsel against adoption of

207. See Truckor, supra note 17, at 365 ("If complicated statistical data would not be enough to make a juror's eyes glaze over, the potentially endless stream of experts who could testify on the patient's membership in a group that would have responded favorably to early diagnosis or treatment would probably finish the job.").

208. In an employment discrimination case involving a probabilistic injury, not only will a plaintiff seek equitable remedies like back pay, front pay, and various forms of injunctive and declaratory relief, see 42 U.S.C. $\$ 2000 \mathrm{e}-5(\mathrm{~g})$, but at least under Title VII and the ADA, she will likely also seek compensatory and punitive damages. See 42 U.S.C. $\S 1981$ a. Although a jury alone could award compensatory and punitive damages, see 42 U.S.C. $\$ 1981$ a(c), the judge could award back pay and front pay as equitable remedies to place the plaintiff in the position she would have been in absent the discriminatory conduct. See Pollard v. E.I. du Pont de Nemours \& Co., 532 U.S. 843, 847-48 (2001) ("Plaintiffs who allege employment discrimination on the basis of sex traditionally have been entitled to such remedies as injunctions, reinstatement, backpay, lost benefits, and attorney's fees under $\S 706(\mathrm{~g})$ of the Civil Rights Act of 1964.") (citations omitted). Pollard also makes clear that front pay is a type of equitable relief under Title VII. Id. at 854 (finding that front pay is a type of equitable remedy under Section $706(\mathrm{~g})$ of Title VII). In this sense, lost chance theory in the employment discrimination context may have a decided advantage over its tort law counterpart to the extent that judges rather than juries will be handling these complex probabilistic calculations. But see Noah, supra note 2 (manuscript at 3 n.3) (discussing computation blunders made by judges in loss of a chance cases).

209. See Biondo, 382 F.3d at 690 . Traditional punitive damages would probably not be available in lost chance employment discrimination cases, as it makes less sense to say that an employer "engaged in a discriminatory practice . . . with malice or with reckless indifference to the federally protected rights of an aggrieved individual," see 42 U.S.C. $\$ 1981 \mathrm{a}(\mathrm{b})(1)$, when the plaintiff had only lost less than a $50 \%$ chance of receiving a competitive position. This is even more so considering the Kolstad court's emphasis on the employer's state of mind, rather than the egregiousness of the conduct. See supra note 193 and accompanying text.

210. See 42 U.S.C. $\S 1981$ a(c)(1) (“(c) Jury trial-If a complaining party seeks compensatory or punitive damages under this section-(1) any party may demand a trial by jury ...."). 
the pure lost chance theory in better-than-even-chance employment discrimination cases because it inappropriately provides additional opportunities to cloud the remedial issues and needlessly increases administrative costs to the litigation system.

\section{A PUBLIC INTEREST MODEL FOR APPLYING LOST CHANCE THEORY TO PROBABILISTIC INJURIES IN EMPLOYMENT DISCRIMINATION CASES}

\section{A. Setting Up the Employment Discrimination Litigation Context for Lost Chance Theory}

In place of pure lost chance theory, this Article advances a public interest approach for remedying probabilistic injuries in employment discrimination litigation. Before setting out the components of this approach, however, it is important to first set out the legal framework for an employment discrimination case to establish at what points the lost chance analysis may come into play.

In a run-of-the-mill intentional employment discrimination case ${ }^{211}$ under Title VII, ${ }^{212}$ the plaintiff has the burden of proving by the preponderance of the evidence that she suffered an adverse employment action because of her race, sex, color, national origin, or religion. ${ }^{213}$ Although there may be different proof frameworks available to the plaintiff depending upon the type of evidence available, ${ }^{214}$ and based on whether the case involves an individual or a group, ${ }^{215}$ the first part of

211. Although there is no evident reason why the public interest model to lost chance theory set forth herein cannot apply to disparate impact claims under section 703(k) of Title VII, id. $\S 2000 \mathrm{e}-2(\mathrm{k})$, for ease of analysis, the following narrative assumes an intentional, disparate treatment employment discrimination case involving either an individual or a group of plaintiffs. See id. $\$ 2000 \mathrm{e}-2(\mathrm{a})$.

212. Although this analysis utilizes Title VII, the same approach to employment discrimination cases generally also exists under the ADEA, 29 U.S.C. $\$ \S 621-633 \mathrm{a}$, the Rehabilitation Act, id. $\S 791$, Section 1981, 42 U.S.C. $\S 1981$, and Title I of the ADA, id. §§ 12101-12118.

213. See 42 U.S.C. $\& 2000 \mathrm{e}-2(\mathrm{a}),(\mathrm{m})$.

214. In individual hiring or promotion cases, a plaintiff may proceed under the McDonnell Douglas Corp. v. Green pretext framework. See Texas Dep't of Cmty. Affairs v. Burdine, 450 U.S. 248, 252-53 (1981) (setting forth the framework established under McDonnell Douglas, 411 U.S. 792 (1973)). A plaintiff may also proceed under the mixed-motive framework codified by the 1991 Act. See 42 U.S.C. $\S \S 2000 \mathrm{e}-2(\mathrm{~m}), 2000 \mathrm{e}-5(\mathrm{~g})(2)(\mathrm{B})$. Nevertheless, there is some question whether the McDonnell Douglas analysis remains viable as a consequence of the U.S. Supreme Court's recent decision in Desert Palace, Inc. v. Costa. 539 U.S. 90 (2003); see also Dare v. Wal-Mart Stores, Inc., 267 F. Supp. 2d 987, 991-92 (D. Minn. 2003) (questioning the continuing validity of the McDonnell Douglas framework in light of Desert Palace). Regardless of how one comes down on this issue, it should not have any impact on the analysis herein.

215. As discussed above, the Teamsters framework applies to systemic disparate 
any such employment discrimination case consists of a plaintiff establishing liability for unlawful discrimination under the applicable framework by the preponderance of the evidence. ${ }^{216}$ Moreover, up to the point when liability attaches, lost chance theory should not play any role in the legal analysis. ${ }^{217}$

Once liability has been established, the defendant may have various substantive defenses at its disposal to either reduce or completely defeat the amount of damages. For instance, in a mixed-motive case under Title VII, the defendant can substantially diminish the amount of damages by establishing by the preponderance of the evidence that it would have made the same decision regarding the plaintiff even in the absence of unlawful discrimination. ${ }^{218}$ Similarly, in a group disparate treatment case, although a presumption of liability for every plaintiff in a group or class is established once liability is proven, the employer may establish that an individual plaintiff in the group is entitled to less or no relief. $^{219}$

As far as the interaction between these employment discrimination substantive defenses and lost chance theory, Judge Posner has suggested that a district judge could "apply [the defendant's burden of proof] to probabilities as distinct from certainties of loss."220 For instance,

[i]f ... the government is able to prove by clear and convincing evidence that Doll had no more than a 20 percent chance of being appointed foreman in lieu of [the other applicant] (had the Veterans Administration complied with the Rehabilitation Act), it will be open to the district judge to

treatment cases under Title VII. As in the individual intentional discrimination cases, the ultimate burden of persuasion is on the plaintiffs during the liability phases of the trial to prove unlawful discrimination. See supra note 122.

216. Regardless of which framework is utilized, "[t]he ultimate burden of persuading the trier of fact that the defendant intentionally discriminated against the plaintiff remains at all times with the plaintiff." See Burdine, 450 U.S. at 253.

217. Although issues of causation must be decided during the liability phase of employment discrimination litigation, lost chance only involves the reconceptualizing of the harm caused by the defendant and then the valuation of that harm. See GrEEN, supra note 2 , at 4 (recogmizing that reconceptualizing the interest harmed is at the heart of the lost chance approach).

218. See 42 U.S.C. $\$ 2000 \mathrm{e}-5(\mathrm{~g})(2)(\mathrm{B})(\mathrm{i})$ (providing that the plaintiff is limited to declaratory relief, specific types of injunctive relief, and attorney fees and costs if the defendant meets the same decision test). Importantly, if the defendant is able to satisfy the same decision test, no form of monetary damages or equitable relief is available. See id. $\S 2000 \mathrm{e}-5(\mathrm{~g})(2)(\mathrm{B})(\mathrm{ii})$.

219. See supra note 122 . Additionally, the defendant may reduce the amount of damages by proving that it would have fired the plaintiff anyway based on derogatory evidence acquired after the plaintiff was discharged for unlawfully discriminatory reasons. See McKennon v. Nashville Banner Publ'g Co., 513 U.S. 352, 357-58 (1995).

220. Doll, 75 F.3d at 1207. 
consider whether to award Doll 20 percent of the back pay that the judge awarded him in the first round of this litigation. ${ }^{221}$

Thus, once the interest harmed is identified as the opportunity of receiving a position, the employer, through its defenses, can adduce evidence to seek to establish the loss of chance the plaintiff actually suffered. ${ }^{222}$ On the other hand, if the defendant cannot meet its burden of persuasion under the same decision test or any other substantive defense, the fact finder will be free to set the percentage lost based on the relevant evidence presented by the parties in the liability phase of the case. $^{223}$

\section{B. The Fundamentals of the Public Interest Model}

Having placed the lost chance remedial theory into the larger employment discrimination litigation context, the following Sections set out the three steps that fact finders should follow in determining how to evaluate a loss of a chance caused by the discriminatory denial of a competitive position.

\section{IDENTIFICATION OF THE INTEREST HARMED}

First, the court must properly identify the interest lost in such probabilistic cases. ${ }^{224}$ The interest harmed is not the ultimate job loss suffered by the plaintiff, but rather the loss of an opportunity to obtain the job without discriminatory conduct being involved. ${ }^{225}$ Thus, the interest harmed in a competitive hiring or promotion case in the employment context is the chance of receiving a position now or in the future (for example, as in the Biondo case). ${ }^{226}$ With regard to causation, the plaintiff must merely show that the employer's discriminatory actions were more likely than not the cause-in-fact of the plaintiff's loss

221. Id.

222. Id. To be clear, in a lost chance case, the employer's defense does not go to whether the plaintiff would have received the job absent discrimination, but whether it was more likely than not that the defendant's conduct caused a certain percentage of lost opportunity in obtaining a job as a result of its unlawful discriminatory conduct. Id.

223. For a discussion of the relevant evidence a fact finder may rcly on to set a plaintiff's percentage of chance lost in an employment discrimination case, see infra Part IV.B.2.

224. See supra notes 49-51.

225. See supra note 66; see also Aagaard, supra note 49, at 1341 ("Courts in these cases must distinguish carefully the losses associated with the tort injury from the losses associated with the plaintiff's underlying injury. This distinction, however, eludes many courts.").

226. 382 F.3d at $684-85$. 
of a chance..$^{227}$ In situations where it is quite clear that only one employer was involved in discriminatorily not selecting the plaintiff for the position in question, establishing that the same employer was the "but for" cause of the plaintiff losing a certain quantum of chance should be relatively easy to establish. ${ }^{228}$

\section{DETERMINATION OF THE PROBABILITY THAT PLAINTIFF WOULD HAVE RECEIVED A POSITION ABSENT UNLAWFUL DISCRIMINATION}

Second, the fact finder will have to determine the probabilities of a given plaintiff having received a job in the absence of discrimination. ${ }^{229}$ As noted previously, this endeavor is much more art than science, ${ }^{230}$ and the fact finder will no doubt have to engage in an empirical approximation. ${ }^{231}$ Nevertheless, there are factors that should play a role in determining the relative likelihood that a plaintiff would have received a position in the absence of discrimination. ${ }^{232}$ For instance, factors such as educational background, relevant past job experience, seniority, and the score on a validated performance test are all relatively objective criteria that the court could use in determining the probability of someone receiving a job. ${ }^{233}$ In addition, each side could employ experts, utilizing comparative data of people who were actually hired or promoted, to determine the likelihood of success in the absence of discrimination. ${ }^{234}$ Finally, the testimony of the plaintiff and other

227. See Noah, supra note 2 (manuscript at 4) (observing that even in lost chance cases, the plaintiff must still "prove by a preponderance of the evidence that the defendant's negligence caused that loss of a chance") (citing King, supra note 5, at 1394-95); see also Jorgensen, 6I6 N.W.2d at 370-71; Aagaard, supra note 49, at 1341. As the South Dakota Supreme Court wrote in Jorgensen: "As a distinct cause of action, the loss of a chance must still be proven under the traditional standard of proof. That is, the plaintiff must still prove ... that the defendant's conduct operated to reduce his chance of a more favorable outcome." 616 N.W.2d at 370-71, abrogated by legislative amendment, S.D. CODIFIED LAWs $\S 20-9-1$.

228. See Aagaard, supra note 49, at 1342.

229. See, e.g., Bishop, 272 F.3d at 1016.

230. Id. at 1016.

231. See supra note 72 .

232. See, e.g., Biondo, 382 F.3d at 689.

233. Id. at 689-90.

234. Weigand, supra note 9, at 310 ("While expert testimony is crucial to all medical malpractice claims, it is especially so in loss of chance claims."); Truckor, supra note 17, at 364-65; see also Albright, 208 F. Supp. 2d at 640-41 (relying on expert testimony to establish the value of the lost promotion to each plaintiff, and then multiplying the promotion value by the probability that each plaintiff would have received the promotion). Of course, to the extent that the administrative costs become too steep because this type of complex and costly evidence must be adduced for a large number of plaintiffs in a class, one could instead rely on the average worker theory utilized by Judge Easterbrook in Biondo. 382 F.3d at 690 ("Because none of the plaintiffs presented comparative evidence, the view most favorable to the plaintiffs as a 
relevant third parties may provide valuable information for a judge seeking to approximate the probability of a plaintiff receiving a job in the absence of discrimination. ${ }^{235}$

Once the judge calculates the initial chance that an individual plaintiff had at receiving a given job, the loss of chance calculation is simpler in the employment discrimination context than in the tort context. ${ }^{236}$ This is because once the employer has discriminated against the plaintiff so that she can no longer receive a position, the postdiscrimination chance at receiving the job is exactly $0 \% .^{237}$ In other words, although the plaintiff may eventually receive equitable or injunctive relief placing her in the same position she would have been in the absence of discrimination, ${ }^{238}$ right after the employer discriminated against her unlawfully she has no chance of receiving the position that has now been filled by someone else. Thus, unlike the tort context in which the fact finder must calculate the odds at survival after the medical malpractice, no such calculation need take place in the employment discrimination context. If the plaintiff had a $25 \%$ chance of receiving a job prior to discrimination, once she is discriminated against and not selected, her loss of chance is also $25 \%$.

\section{DIVIDING PLAINTIFFS INTO APPROPRIATE LOST CHANCE CATEGORIES}

Third, and finally, depending upon the probabilities calculated, plaintiffs will be divided into three categories: better-than-even-chance plaintiffs, not-better-than-even-chance plaintiffs, and de minimis plaintiffs. ${ }^{239}$ For those who are able to establish that they had more than

group is that each would have done as well as the average lieutenant on the 1992 and 1998 exams.").

235. Truckor, supra note 17, at 364-65. But see Biondo, 382 F.3d at 689-90 (criticizing the use of some of these forms of evidence to determine probabilities).

236. See Noah, supra note 2 (manuscript at 26).

237. In this sense, employment discrimination injuries are like those injuries in medical malpractice cases where the doctor absolutely destroys any chance a patient had at survival. Id.

238. See supra note 208.

239. Regardless of whether there is one plaintiff or multiple plaintiffs, the employer may still be undercompensating or overcompensating the plaintiff under the public interest model. This outcome is the result of the existence of some probability that the selected candidate (that is, the individual that is not discriminated against) would have been offered the position in the absence of discrimination. See infra tbl.B. The advantage of the public interest approach to lost chance, nonetheless, includes the fact that less-than-even-chance plaintiffs will receive some compensation for their losses caused by a clearly discriminatory employer rather than none. Furthermore, in betterthan-even-chance cases, the overcompensation can be written off as equitable relief necessary for the fulfillment of employment discrimination law's public-regarding purposes. See supra notes $183-86$ and accompanying text. 
a $50 \%$ chance of receiving a job in the absence of discrimination, the public interest model awards the full value of the job ${ }^{240}$ to effectuate the public interests sought to be vindicated by employment discrimination law. ${ }^{241}$ This is also necessary to be consistent with traditional causation standards. ${ }^{242}$ On the other hand, for those who establish a $50 \%$ chance or less of receiving a job in the absence of discrimination, lost chance theory will be applied to provide the plaintiff with an award that is equivalent to the total value of the job multiplied by the percentage of the lost chance. ${ }^{243}$ Finally, for administrative cost reduction purposes and to prevent frivolous claims from reaching the courthouse, those plaintiffs establishing less than a $10 \%$ chance of receiving a job in the absence of discriminatory treatment will be precluded from recovering. . $^{24}$

\section{A Hypothetical Illustration of the Public Interest Model}

To better illustrate how the public interest model will work in practice, it is helpful to consider a hypothetical employment discrimination case involving the denial of a competitive promotion for unlawful discriminatory reasons. Under the facts of this case, $A B C$ Corporation has a standard operating procedure of not promoting African Americans to positions of responsibility in their organization. During the most recent round of promotions, the employer considered five applicants for the position of Lead Supervisor, four African American employees and one white employee. As a result of the selection process, the white applicant was selected.

240. The "full value of the job" refers primarily to a combination of back pay, front pay, or reinstatement, which the judge will determine in her discretion. See supra note 208. Even if there is a jury seated to determine compensatory or punitive damages, these monetary awards should not impact the judge's lost chance calculations. See Biondo, 382 F.3d at 690 . This is because the damages for emotional distress and egregious conduct will most likely be discounted (or in the case of punitive damages, not awarded at all) as a result of the jury considering the likelihood of a plaintiff having received a position absent discrimination. Id. In any event, such calculations should not affect the judge's equitable determination concerning what the job is worth in terms of back pay, front pay, or reinstatement. Id.

24I. See supra note 25 . One additional interesting issue that will need to be addressed when determining the "full value of the job" is when the applicable limitations period accrues. See Weigand, supra note 9 , at 309 . Because the interest harmed in loss chance cases is the loss of an opportunity, the limitations period should start to run at the time the opportunity is denied, not when the ultimate harm occurs. Id. However, this confusion should not arise in the employment discrimination context, as the time the opportunity is denied and the time when the ultimate harm occurs are the same. See supra Part IV.A.2.

242. See supra notes $195-99$ and accompanying text.

243. See supra notes $67-70$ and accompanying text.

244. See supra notes 81-85 and accompanying text. 
Unhappy with the outcome of the selection process, three out of the four African American employees bring a pattern and practice disparate treatment case under the Teamsters model alleging a systemic policy of unlawfully excluding African Americans from supervisory positions, in violation of Title VII. ${ }^{245}$ The evidence establishes quite clearly that the candidates all had the necessary educational background for the position in question, but that the candidates' past relevant job experience could be divided into three all-inclusive groups: extensive, moderate, and minimal. As it turns out, the white employee selected for the promotion had moderate experience.

The African American employees are able to successfully show during the liability phase of the trial that the employer engaged in unlawful race discrimination in violation of Title VII. ${ }^{246}$ Consequently, a presumption is established that each plaintiff is entitled to some level of relief. ${ }^{247}$ Nevertheless, $A B C$ Corporation still has the ability to show that one or more of the individual plaintiffs is not entitled to relief. ${ }^{248}$ Assuming for the sake of the argument that $A B C$ Corporation cannot meet its burden during the damages phase of the trial, ${ }^{249}$ the judge ${ }^{250}$ turns to the public interest approach to lost chance theory to fashion a remedy for the three successful plaintiffs.

First, the judge identifies the interests harmed by $A B C$ Corporation's wrongful actions. The judge identifies the harm as the loss of chance of the three African American plaintiffs to receive the promotion in question. Next, he determines that one African American plaintiff, Plaintiff $A$ with extensive experience, had a $52 \%$ chance (that is, a better-than-even chance) of receiving the job absent discrimination, and therefore, awards the full value of the job to that plaintiff by awarding back pay and instating her into the supervisor position. ${ }^{251}$

245. For a discussion of the Teamsters framework for systemic disparate treatment cases, see supra note 122.

246. To reiterate, for liability to attach, there is no need to undertake a lost chance calculation at this stage of the litigation. See supra Part IV.A.

247. See supra note 122 .

248. Id.

249. In a real case, the $A B C$ Corporation might be able to prove that Plaintiff $C$ with only mimimal experience would not have received the promotion under any circumstances. Notice, however, that because the public interest model applies a $10 \%$ de minimis threshold, the result is the same regardless of the phase in which lost chance applies. See supra tbl.A.

250. For the sake of simplicity, this hypothetical assumes that no compensatory or punitive damages are being requested. For a further discussion regarding whether a judge or jury should make loss chance calculations in employment discrimination litigation, see supra notes 207, 240.

251. If instatement is inappropriate because of hostility, or because the plaintiff is already working at a different job at a different company, front pay may be utilized as an equitable remedy to place the plaintiff in the position he would have been in absent discrimination. See Graefenhain v. Pabst Brewing Co., 870 F.2d 1198, 1212 (7th Cir. 
As for the remaining two African American plaintiffs, Plaintiff $B$ has moderate experience and Plaintiff $C$ has minimal experience, thus each has a not-better-than-even chance of receiving the position. Additionally, the other nonplaintiff African American employee had minimal experience. To value the chance of each of these individuals to receive the job, the judge establishes in total that these four remaining applicants combined (the two remaining plaintiffs, the one African American nonplaintiff and the successful white applicant) had a $48 \%$ chance of receiving the job, and that because of differences in experience, the moderate experience candidates had a $16 \%$ chance of receiving the job, whereas the minimal experience candidates had an $8 \%$ chance of receiving the job. Based on these valuations, the judge awards Plaintiff $B 16 \%$ of the value of the job and awards Plaintiff $C$ nothing under the de minimis exception. ${ }^{252}$

Table B

Hypothetical Applying Lost Chance (Public Interest Model) to $A B C$ Corporation Scenario

\begin{tabular}{|c|c|c|c|}
\hline Plaimtiffs & Experience & $\begin{array}{c}\text { Chance of } \\
\text { Obtaining Job }\end{array}$ & Remedy \\
\hline Plaintiff $A$ & Extensive & $52 \%$ & $\begin{array}{c}100 \% \text { of } \\
\text { Value of } \\
\text { Job }\end{array}$ \\
\hline Plaintiff $B$ & Moderate & $16 \%$ & $\begin{array}{c}16 \% \text { of Value } \\
\text { of Job }\end{array}$ \\
\hline PIaintiff $C$ & Minimal & $8 \%$ & $\begin{array}{c}0 \% \text { (De } \\
\text { Minimis) }\end{array}$ \\
\hline
\end{tabular}

1989) (observing that an award of front pay should make a plaintiff whole in the absence of reinstatement).

252. See supra notes $82-85$ for the advantages of adopting de minimis exception.

253. "Value of the job" as utilized in these Tables refers to some combination of back pay, front pay, or instatement that represents how much a plaintiff lost by being denied a competitive position on the basis of unlawful discrimination. See supra note 235. 


\section{Table C}

Hypothetical Applying Lost Chance (Pure Version) to $A B C$ Corporation $\underline{\text { Scenario }}$

\begin{tabular}{|c|c|c|c|}
\hline Plaintiffs & Experience & $\begin{array}{c}\text { Chance of } \\
\text { Obtaining Job }\end{array}$ & Remedy \\
\hline Plaintiff $A$ & Extensive & $52 \%$ & $\begin{array}{c}52 \% \text { of } \\
\text { Value of } \\
\text { Job }\end{array}$ \\
\hline Plaintiff $B$ & Moderate & $16 \%$ & $\begin{array}{c}16 \% \text { of } \\
\text { Value of } \\
\text { Job }\end{array}$ \\
\hline Plaintiff $C$ & Minimal & $8 \%$ & $\begin{array}{c}8 \% \text { of } \\
\text { Value of } \\
\text { Job }\end{array}$ \\
\hline
\end{tabular}

Table D

Hypothetical Applying Traditional All-or-Nothing Approach to $A B C$ Corporation Scenario

\begin{tabular}{|c|c|c|c|}
\hline Plaintiffs & Experience & $\begin{array}{c}\text { Chance of } \\
\text { Obtaining Job }\end{array}$ & Remedy \\
\hline Plaintiff $A$ & Extensive & $52 \%$ & $\begin{array}{c}100 \% \text { of } \\
\text { Value of } \\
\text { Job }\end{array}$ \\
\hline Plaintiff $B$ & Moderate & $16 \%$ & $0 \%$ \\
\hline Plaintiff $C$ & Minimal & $8 \%$ & $0 \%$ \\
\hline
\end{tabular}

\section{Preliminary Conclusions Regarding the Public Interest Model}

In reviewing the results of the hypothetical discussed above, three preliminary conclusions are possible. First, the public interest approach to lost chance theory represents a principled compromise for meeting the sometimes contradictory public and private aims of employment discrimination law. ${ }^{254}$ As a compromise to these sometimes intractable issues, it will hopefully satisfy, to some extent, both law and economic adherents who focus on proper deterrence and allocation of resources, ${ }^{255}$ as well as those who favor the relative simplicity of the traditional allor-nothing approach.

Second, and as a result of the factual circumstances surrounding the

254. See Truckor, supra note 17 , at 373 (describing the lost chance approach as a compromise between the all-or-nothing approach and relaxed causation approach).

255. See supra note 25 . 
hypothetical example, notice that under the public interest model, the employer ends up paying a total of $116 \%$ of the value of the job for which it discriminatorily selected the white candidate, as compared to $100 \%$ under the all-or-nothing approach. ${ }^{256}$ This additional $16 \%$ of compensation can be viewed as a punitive-type of equitable relief awarded to the plaintiffs in order to support the public goals of employment discrimination law,,$^{257}$ as well as at least symbolically making the employer acknowledge that its own bad conduct caused not only victim specific damage, but harm to society in general. ${ }^{258}$

Third, and finally, the valuation process, as demonstrated above, remains more of an exercise in approximation rather than an attempt to arrive at a mathematically pure figure. Nevertheless, and as discussed by other jurists and commentators, ${ }^{259}$ this fact alone should not undermine lost chance theory as a viable way of justly compensating those who have suffered at the hands of a discriminatory employer. ${ }^{260}$ Indeed, such an approach is a modern day slicing of the Gordian Knot;

256. Interestingly, the pure lost chance model leads to the undercompensation of all three plaintiffs by a total of $8 \%$ because of the fact that one black employee did not join in the lawsuit against the employer. See supra tbl.C. This result again suggests that a mandatory joinder motion under Rule 19 of the Federal Rules of Civil Procedure should be utilized to prevent systemic undercompensation in pure lost chance theory cases. See supra note 156 (discussing the advantages of a Rule 19 motion in this context).

257. In this regard, although the all-or-nothing approach is successful in providing meaningful "make whole" relief for one of the plaintiffs, it ignores the fact that the employer's conduct also had a more than a de minimis impact on Plaintiff $B$. See Wax, supra note 5, at 1214. As Amy Wax wrote: "If race or sex is found to be the 'determinative' cause of an adverse employment action, then the victim obtains a full 'make whole' measure of relief. If that finding is not made, the claimant gets nothing." Id. Thus, one of the chief advantages of the public interest model over the all-ornothing approach is that it does not completely ignore reprehensible conduct against one of the plaintiffs as though it never happened. See supra note 48,51 .

258. And thus, overcoming the current overemphasis on monetary relief in these types of cases. See Selmi, supra note 21, at 1251-52.

259. See Bishop, 272 F.3d at 1016 (observing that lost chance calculations are more art than science); Aagaard, supra note 49, at 1350 (arguing for a discretionary approach to valuing the loss of chances).

260. See Doll, 75 F.3d at 1206-07. As the court stated in Doll:

It would be hard to pick a number that would reliably estimate the probability of Doll's receiving the promotion but for discrimination. Would it be 5 percent? 10 percent? 40 percent? Who knows? Yet no less uncertainty attends the efforts of triers of fact to fix the percentage of a plaintiff's negligence in a tort case governed, as most tort cases are today, by the rule of comparative negligence.

Id.; see, e.g., Wassell v. Adams, 865 F.2d 849 (7th Cir. 1989) (upholding an allocation of $97 \%$ of the fault to the plaintiff). If the uncertainty is bearable there, why is it not bearable in an employment case? The unarticulated, unacknowledged difference-splitting that the plaintiff thinks the judge engaged in here does not appear to be a superior approach. 
that is, it represents the most bold and energetic remedial method for comprehensively meeting the two central statutory purposes of employment discrimination law. ${ }^{261}$

The public interest model to lost chance for probabilistic injuries in employment discrimination cases adopted in this Article represents the best accommodation of the public and private interests sought to be advanced by employment discrimination law. On one hand, it provides compensation for those who have been wronged and would receive no recovery under the traditional all-or-nothing approach. ${ }^{262}$ On the other hand, this approach serves the public interest by awarding punitive-like equitable relief to employees who had a better-than-even chance of receiving a position in the absence of discrimination, thereby furthering the public goal of eradicating all forms of discrimination from the workplace. $^{263}$

\section{CONCLUSION}

Applying lost chance theory to probabilistic injuries in competitive hiring and promotion cases in the employment discrimination context generally leads to more just and equitable results than any other remedial scheme. Nevertheless, this Article seeks to amend the pure lost chance theory approach advocated elsewhere with the public interest model. Under this public interest model, lost chance theory is applied only to not-better-than-even-chance employment discrimination cases with at least a $10 \%$ loss of chance of initially obtaining a competitive position. At the same time, the traditional all-or-nothing approach continues to apply to better-than-even-chance cases. The benefit to be gained from this hybrid approach is that the public interest goals underlying employment discrimination law will again be appropriately given prominence. To the extent that overcompensation results because of this remedial scheme, such additional compensation should be seen as a punitive-like equitable remedy, necessary to effectuate the broader public policy mandate of federal employment discrimination law: to eradicate unlawful employment discrimination throughout the economy.

261. See supra note 140.

262. In the hypothetical, Plaintiff $B$ represents the plaintiff who would be othcrwise undercompensated under the traditional all-or-nothing approach. Compare supra tbl.B, with supra tbl.D.

263. See supra notes 181-86 and accompanying text. 